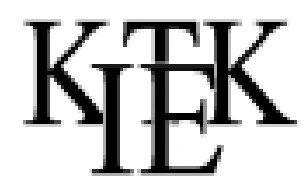

DISCUSSION PAPERS

NEW SERIES

MÜHELYTANULMÁNYOK

ÚJ SOROZAT

MT-DP. 2002/13

\title{
PREEMPTIVE HORIZONTAL MERGERS: THEORY AND EVIDENCE
}

\author{
JÓZSEF MOLNÁR
}

Institute of Economics

Hungarian Academy of Sciences

Budapest 


\title{
PREEMPTIVE HORIZONTAL MERGERS: \\ THEORY AND EVIDENCE
}

\author{
JÓZSEF MOLNÁR
}


KTK/IE Discussion Papers 2002/13

Institute of Economics Hungarian Academy of Sciences

KTK/IE Discussion Papers are circulated to promote discussion and provoque comments. Any references to discussion papers should clearly state that the paper is preliminary. Materials published in this series may subject to further publication.

The paper was selected for the $2^{\text {st }}$ Budapest Summer Workshop for young economists, organised by the KTK/IE on 24-25 June 2002.

The Budapest Summer Workshops intend to bring together young economists with foreign $\mathrm{PhD}$ education, frequently still working or studying abroad.

\section{Preemptive Horizontal Mergers: Theory and Evidence}

Author: József MOLNÁR, Department of Economics, Northwestern University. 2003 Sheridan Road, Evanston IL 60208.

E-mail: j-molnar@nwu.edu

I am greatly indebted to my dissertation chair, William Rogerson for his encouragement and insight. My advisors: Robert Porter, Todd Pulvino, Asher Wolinsky have been very helpful and supportive. I also thank Kent Daniel, Michael Fishman, Thomas Geragthy, Thomas Lys, Robert McDonald, Robert Vigfusson, Thomas Wiseman, Mark Witte and especially Péter Eső and Yossi Spiegel, for their helpful comments. All remaining errors are mine. Financial support from Northwestern University Graduate Research Grant and from The Center for the Study of Industrial Organization at Nortwestern University is gratefully acknowledged.

ISSN 1419-6328

ISBN 9639321648

Published by the Institute of Economics Hungarian Academy of Sciences, Budapest, 2002.

With financial support of the Hungarian Economic Foundation 


\section{The Publications of the Institute of Economics}

BUDAPEST WORKING PAPERS

ON THE LABOUR MARKET

BUDAPESTI

MUNKAGAZDASÁGTANI FÜZETEK

\begin{tabular}{|c|c|c|}
\hline BWP. 2001/1 & János Köllö & $\begin{array}{l}\text { The patterns of non-employment in Hungary's least developed } \\
\text { regions }\end{array}$ \\
\hline BWP. 2001/2 & Köllő János & $\begin{array}{l}\text { A munkanélküli segélyrendszer 2000. évi szigorításának politi- } \\
\text { kai támogatottsága }\end{array}$ \\
\hline BWP 2001/3 & $\begin{array}{l}\text { Kertesi Gábor- } \\
\text { Köllő János }\end{array}$ & Ágazati bérkülönbségek Magyarországon \\
\hline BWP 2001/4 & $\begin{array}{l}\text { Gábor Kertesi and } \\
\text { János Köllö }\end{array}$ & $\begin{array}{l}\text { Economic transformation and the revaluation of human capital - } \\
\text { Hungary, 1986-1999 }\end{array}$ \\
\hline BWP 2001/5 & $\begin{array}{l}\text { Galasi Péter- } \\
\text { Nagy Gyula }\end{array}$ & Járadékjogosultság és elhelyezkedési esélyek \\
\hline BWP 2001/6 & $\begin{array}{l}\text { Kertesi Gábor- } \\
\text { Köllő János }\end{array}$ & $\begin{array}{l}\text { A gazdasági átalakulás két szakasza és az emberi tőke átérté- } \\
\text { kelődése }\end{array}$ \\
\hline BWP 2001/7 & Köllő János & $\begin{array}{l}\text { A járadékos munkanélküliek álláskilátásai } 1994 \text { és } 2001 \text { tava- } \\
\text { szán }\end{array}$ \\
\hline BWP 2001/8 & $\begin{array}{l}\text { Galasi Péter- } \\
\text { Nagy Gyula }\end{array}$ & $\begin{array}{l}\text { A munkanélküli ellátás változásainak hatása a munkanélküliek } \\
\text { segélyezésére és elhelyezkedésére }\end{array}$ \\
\hline BWP 2001/9 & Fazekas Károly & $\begin{array}{l}\text { Az aktív korú állástalanok rendszeres szociális segélyezésével és } \\
\text { közcélú foglalkoztatásával kapcsolatos önkormányzati tapasztalatok }\end{array}$ \\
\hline BWP 2001/10 & Júlia Varga & $\begin{array}{l}\text { Earnings Expectations and Higher Education Enrolment Deci- } \\
\text { sions in Hungary }\end{array}$ \\
\hline BWP 2001/11 & Köllö János & Meddig tart a rendszerváltás? \\
\hline BWP 2002/1 & $\begin{array}{l}\text { Péter Galasi- } \\
\text { Júlia Varga }\end{array}$ & $\begin{array}{l}\text { Does Private and Cost-Priced Higher Education: Produce Poor } \\
\text { Quality? }\end{array}$ \\
\hline BWP 2002/2 & Köllö János & $\begin{array}{l}\text { Az ingázási költségek szerepe a regionális munkanélküli kü- } \\
\text { lönbségek fenntartásában - Becslési kísérletek }\end{array}$ \\
\hline BWP 2002/3 & Gábor Kézdi & $\begin{array}{l}\text { Two Phases of Labor Market Transition in Hungary: Inter- } \\
\text { Sectoral Reallocation and Skill-Biased Technological Change }\end{array}$ \\
\hline BWP 2002/4 & Gábor Körösi & Labour Adjustment and Efficiency in Hungary \\
\hline BWP 2002/5 & $\begin{array}{l}\text { Gábor Kertesi and } \\
\text { János Köllő }\end{array}$ & $\begin{array}{l}\text { Labour Demand with Heterogeneous Labour Inputs after the } \\
\text { Transition in Hungary, 1992-1999 - and the Potential Conse- } \\
\text { quences of the Increase of Minimum Wage in } 2001 \text { and } 2002\end{array}$ \\
\hline BWP 2002/6 & Fazekas Károly & $\begin{array}{l}\text { A tartós munkanélküliek rendszeres szociális segélyezése és } \\
\text { önkormányzati közfoglalkoztatása Magyarországon 2000-2001- } \\
\text { ben }\end{array}$ \\
\hline
\end{tabular}

LABOUR ECONOMICS RESEARCH

(Publications upon conferences organized with Labour Science Committee)

Munkaerőpiac és regionalitás az átmenet időszakában.

Bp., 1998. Szerk.: Fazekas K.

A munkaügyi kapcsolatok rendszere és a munkavállalók helyzete. Bp., 2000. Szerk.: Koltay J.

Oktatás és munkaerőpiaci érvényesülés.

Bp., 2001. Szerk.: Semjén A.

\section{LABOUR MARKET SURVEY - YEARBOOKS}

Munkaerőpiaci tükör - 2000. Budapest, 2000.

Szerk.: Fazekas K.

Munkaeröpiaci tükör - 2001. Budapest, 2001.

Szerk.: Fazekas K.

The Hungarian Labour Market - Review and Analysis, 2002. Bp., 2002

Eds.: K. Fazekas, J. Koltay 


\begin{tabular}{|c|c|c|}
\hline MT-DP. 2001/1 & Mária Csanádi & $\begin{array}{l}\text { A Model Explaining Social and Political Change of } \\
\text { Party-states }\end{array}$ \\
\hline MT-DP. 2001/2 & $\begin{array}{l}\text { Imre FERTŐ and } \\
\text { Lionel J. HUBBARD }\end{array}$ & $\begin{array}{l}\text { Competitiveness and comparative advantage in Hun- } \\
\text { garian agriculture }\end{array}$ \\
\hline MT-DP. 2001/3 & Attila RÁTFAI & $\begin{array}{l}\text { Relative Price Skewness and Inflation: A Structural } \\
\text { VAR Framework }\end{array}$ \\
\hline MT-DP. 2001/4 & $\begin{array}{l}\text { In Ho LEE, Ádám SZEIDL, } \\
\text { Ákos VALENTINYI }\end{array}$ & Contagion and State Dependent Mutations \\
\hline MT-DP. 2001/5 & MOLNÁR György & $\begin{array}{l}\text { Kutatás-fejlesztés, tudóscsere és együttmüködés az } \\
\text { EU-val a magyar iparban }\end{array}$ \\
\hline MT-DP. 2001/6 & $\begin{array}{l}\text { Imre FERTŐ and } \\
\text { Lionel J. HUBBARD }\end{array}$ & $\begin{array}{l}\text { Intra-Industry Trade in Agri-Food Products between } \\
\text { Hungary and EU }\end{array}$ \\
\hline MT-DP. 2001/7 & FERTÖ Imre & A földreformok politikai gazdaságtana \\
\hline MT-DP. 2001/8 & Réka HORVÁTH & Cooperative research and firm performance \\
\hline MT-DP. 2001/9 & $\begin{array}{l}\text { L. AMBRUS-LAKATOS } \\
\text { and Tamás MESZERICS }\end{array}$ & $\begin{array}{l}\text { An Experimental Analysis of the Ultimatum Game: } \\
\text { The Role of Competing Motivations }\end{array}$ \\
\hline MT-DP.2001/10 & Éva NAGYPÁL & $\begin{array}{l}\text { Fixed-Term Contracts in Europe: A Reassessment in } \\
\text { Light of the Importance of Match-Specific Learning }\end{array}$ \\
\hline MT-DP.2001/11 & Balázs VÁRADI & $\begin{array}{l}\text { Multiproduct Cost Function Estimation for American } \\
\text { Higher Education: Economies of Scale and Scope }\end{array}$ \\
\hline MT-DP.2001/12 & $\begin{array}{l}\text { József MOLNÁR and } \\
\text { Gábor VIRÁG }\end{array}$ & Optimal auctions with externalities and signaling \\
\hline MT-DP.2001/13 & $\begin{array}{l}\text { Beatrix PAÁL and } \\
\text { Bruce D. SMITH }\end{array}$ & $\begin{array}{l}\text { The sub-optimally of the Friedman rule and the opti- } \\
\text { mum quantity of money }\end{array}$ \\
\hline MT-DP.2001/14 & Péter BENCZÚR & $\begin{array}{l}\text { Learning. noise traders, the volatility and the level of } \\
\text { bond spreads }\end{array}$ \\
\hline MT-DP.2001/15 & $\begin{array}{l}\text { KAPITÁNY Zsuzsa- } \\
\text { MOLNÁR György }\end{array}$ & $\begin{array}{l}\text { A magyar háztartások jövedelmi-kiadási egyenlötlen- } \\
\text { ségei és mobilitása 1993-1995 }\end{array}$ \\
\hline MT-DP. 2002/1 & NAGY András & $\begin{array}{l}\text { Az intézmények átalakulása és a fejlett gazdaságok } \\
\text { utolérése }\end{array}$ \\
\hline MT-DP. 2002/2 & $\begin{array}{l}\text { Imre FERTŐ and } \\
\text { Lionel J.HUBBARD }\end{array}$ & $\begin{array}{l}\text { Intra-Industry Trade in Horizontally and Vertically } \\
\text { Differentiated Agri-Food Products between Hungary } \\
\text { and the EU }\end{array}$ \\
\hline MT-DP. 2002/3 & $\begin{array}{l}\text { Berthold HERRENDORF } \\
\text { and Ákos VALENTINYI }\end{array}$ & $\begin{array}{l}\text { On the Stability of the Two-sector Neoclassical } \\
\text { Growth Model with Externalities }\end{array}$ \\
\hline MT-DP. 2002/4 & $\begin{array}{l}\text { Zsuzsa KAPITÁNY and } \\
\text { György MOLNÁR }\end{array}$ & $\begin{array}{l}\text { Inequality and mobility analysis by the Hungarian } \\
\text { Rotation Panel, 1993-98 }\end{array}$ \\
\hline MT-DP. 2002/5 & Attila HAVAS & $\begin{array}{l}\text { Does innovation policy matter in a transition country? } \\
\text { - The case of Hungary }\end{array}$ \\
\hline MT-DP. 2002/6 & Attila HAVAS & $\begin{array}{l}\text { Identifying Challenges and Developing Visions } \\
- \text { Technology Foresight in Hungary }\end{array}$ \\
\hline MT-DP. 2002/7 & FERTÖ Imre & A komparatív előnyök mérése \\
\hline MT-DP. 2002/8 & $\begin{array}{l}\text { Imre FERTŐ and } \\
\text { Lionel J.HUBBARD }\end{array}$ & $\begin{array}{l}\text { Revealed Comparative Advantage and Competitive- } \\
\text { ness in Hungarian Agri-Food Sectors }\end{array}$ \\
\hline MT-DP. 2002/9. & $\begin{array}{l}\text { Berthold HERRENDORF } \\
\text { and Ákos VALENTINYI }\end{array}$ & $\begin{array}{l}\text { Determinacy Throught Intertemporal Capital Adjust- } \\
\text { ment Costs }\end{array}$ \\
\hline MT-DP. 2002/10 & $\begin{array}{l}\text { Imre FERTŐ and } \\
\text { Gábor G. SZABÓ }\end{array}$ & $\begin{array}{l}\text { Vertical Co-ordination in Transition Agriculture: a } \\
\text { Hungarian Co-operative Case Study }\end{array}$ \\
\hline MT-DP. 2002/11 & $\begin{array}{l}\text { András SEMJÉN and } \\
\text { István János TÓTH }\end{array}$ & $\begin{array}{l}\text { Unofficial Economic Activities and Fiscal Discipline in } \\
\text { Hungary }\end{array}$ \\
\hline MT-DP. 2002/12 & HERMANN Zoltán & $\begin{array}{l}\text { A helyi iskola müködésének hatása a migrációra a } \\
\text { kistelepüléseken }\end{array}$ \\
\hline MT-DP. 2002/13 & József MOLNÁR & Preemptive Horizontal Mergers: Theory and Evidence \\
\hline
\end{tabular}

Copies of both series are available from Ms. Zsuzsa Sándor, Library of Institute of Economics H-1502 Budapest P.O.Box 262 Fax: (36-1) 319-3136 E-mail address: biblio@econ.core.hu

Papers can be downloaded from the homepage of the Institute of Economics: www.econ.core.hu 


\title{
Preemptive Horizontal Mergers: \\ THEORY AND EVIDENCE
}

JÓZSEF MOLNÁR

\begin{abstract}
This paper proposes an explanation of why it can be rational for the profit-maximizing managers of an acquiring firm to conduct a takeover, even when doing so reduces shareholder value. If a firm fears that one of its rivals will gain competitive advantage from taking over some third firm, $i$ can be rational for the first firm to preempt this merger with a takeover attempt of its own. This attempt can be optimal even if it requires the first firm to "overpay" relative to the increase in the joint profits of the combined firms. The paper first presents a model formalizing the above intuition. Then an event study is conducted to test the preemption theory. The empirical results are consistent with the predictions of the preemption theory, as opposed to the alternatives of hubris and agency theories.
\end{abstract}

\section{CÍM}

MOLNÁR JÓZSEF

Összefoglaló

A cikk alternativ magyarázatot ad arra, hogy miért lehet ésszerü egy felvásárló vállalat vezetőinek egy felvásárlást végrehajtani még akkor is, ha ezzel csökkentik a részvényesek jólétét. Ha egy vállalat attól tart, hogy egy riválisa versenyelönyre tehet szert egy másik vállalat felvásárlásával, akkor egy megelözö felvásárlás racionális lehet, még az esetben is, ha ez azzal jár, hogy az elsö vállalatnak többet kell fizetnie, mint a felvásárlásból származó profit-növekmény. A cikk elöször egy, a fenti intuiciót formalizáló modellt mutat be, majd, a második részben egy esettanulmanyon keresztül teszteli a "megelözési elmélet" elörejelzéseit. Az empirikus eredmények igazolják a megelözési elméletet az alternativ arrogancia és ügynök elméletek ellenében. 



\title{
Preemptive Horizontal Mergers: Theory and Evidence*
}

\author{
Jozsef Molnar $^{\dagger}$
}

October 28,2000

\begin{abstract}
This paper proposes an explanation of why it can be rational for the profitmaximizing managers of an acquiring firm to conduct a takeover, even when doing so reduces shareholder value. If a firm fears that one of its rivals will gain competitive advantage from taking over some third firm, it can be rational for the first firm to preempt this merger with a takeover attempt of its own. This attempt can be optimal even if it requires the first firm to "overpay" relative to the increase in the joint profits of the combined firms. The paper first presents a model formalizing the above intuition. Then an event study is conducted to test the preemption theory. The empirical results are consistent with the predictions of the preemption theory, as opposed to the alternatives of hubris and agency theories.
\end{abstract}

${ }^{*}$ I am greatly indebted to my dissertation chair, William Rogerson for his encouragement and insight. My advisors: Robert Porter, Todd Pulvino, Asher Wolinsky have been very helpful and supportive. I also thank Kent Daniel, Michael Fishman, Thomas Geragthy, Thomas Lys, Robert McDonald, Robert Vigfusson, Thomas Wiseman, Mark Witte and especially Peter Eso and Yossi Spiegel, for their helpful comments. All remaining errors are mine. Financial support from Northwestern University Graduate Research Grant and from The Center for the Study of Industrial Organization at Northwestern University is gratefully acknowleged.

$\dagger$ Affiliation: Department of Economics, Northwestern University. 2003 Sheridan Road, Evanston IL 60208. E-mail: j-molnar@nwu.edu 


\section{Introduction}

A number of empirical studies examine the extent to which takeovers improve target and bidder firms' value. The evidence indicates that the acquired firm's shareholders benefit, and that the acquiring firm's shareholders are either worse off or at best unaffected (Jensen and Ruback 1983). ${ }^{1}$ These facts seem to be inconsistent with the neoclassical assumptions of rationality and profit-maximization. If mergers are driven by profit-maximization, then why do executives of the acquiring firms often pay more for the target than is justified by its market value? Existing theories explain this puzzle by questioning the rationality of managers or their commitment to shareholder value-maximizing behavior. ${ }^{2}$

The first part of this paper proposes a new theory of why acquiring firms pursue value-decreasing horizontal mergers even if managers are rational and trying to maximize shareholders' value. If a firm fears that one of its rivals will gain large cost savings or efficiencies from taking over some third firm, then it can be rational for the first firm to preempt this merger with a takeover attempt of its own. By preempting the rival firm's bid, the first firm avoids the reduced profits it would have suffered had its rival been successful, but its post-merger profit could still decrease relative to its pre-merger profit. This preemption can be optimal even if it requires the first firm to overpay relative to the increase in the joint profits of the combined firms. ${ }^{3}$ In this case, preemption decreases

\footnotetext{
${ }^{1}$ Bradley, Desai and Kim (1988) and studies surveyed by Jarell, Brickley and Netter (1988) found steadily decreasing returns to acquiring companies from the 1960s through the 1980s. Recent work by Betton and Eckbo (1999) and Schwert (1996) support these findings. Healy et. al. (1992) found that industry-adjusted performace of the merging firms improved in the postmerger period. For an extensive literature review see Weston, Chung and Siu (1997) and Sirower (1997).

${ }^{2}$ Roll (1986) proposes the "hubris" hypothesis to explain why many acquiring firms incur losses. Suppose that there are no possible gains in a takeover activity. According to Roll, managers trust their own valuations more than they trust the market valuation, and they will attempt takeovers only when they believe they have found undervalued firms. If the market and managers (on average) are both correct, takeover attempts will only occur in firms where managers' estimates are overly optimistic and so above the average. As a result they will incur losses in takeovers. According to this theory, managers, because of their hubris, refuse to account for the biases in their estimates. This behavior parallels that of unsophisticated bidders in a common value auction, who do not adjust for the "winner's curse."

Agency problems have been identified as another possible cause for loss-incurring acquisitions. Managers of acquiring firms may not be acting in the best interest of shareholders while making acquisition decisions. Several motives have been assigned to managers for going on an acquisition binge. Some examples are: diversification of managers' personal portfolios (Amihud and Lev 1981), the use of free cash flow to increase the size of the firm (Jensen 1976), and a desire to increase the size of the firm so that it becomes more dependent upon its management (Shleifer and Vishny 1989).

${ }^{3}$ Fishman (1988) also studies a preemptive motive for merger. However in his model the preemption happens in the bidding phase and he does not consider the strategic effect of the downstream competition.
} 
the net profits of both the rival and the merged firms. In an efficient stock market, stock prices reflect current and expected future net profits. If discounted cash flow falls, the stock price must also fall (ceteris paribus).

In the first part of the paper a two-stage model is presented to formalize this intuition. In the first stage, firms decides how much they want to bid for the target firm depending on the synergies that can be realized after the merger. In the second stage the remaining firms compete in the downstream, post-merger market. Subgame-perfect Nash equilibrium is used as a solution concept. Thus, the analysis is conducted backward from the last stage to the first. If the merger is privately profitable for one firm, without considering the price, then it is profitable for its rival as well. Therefore, when a firm is calculating its willingness to pay to purchase the takeover target, it should rationally expect that their its will purchase the target if it does not. When there are large cost-savings from the merger, firms not involved in the merger are actually hurt by the more efficient merged rival. The benefit of the merger is not only the increased efficiency after the merger but the rival is prevented from purchasing the takeover target as well. Considering this, each firm calculates its operating profit in the second stage as if it were or as if the rival were merging with the target firm. These values define the value of the target firm for each potential acquirer. Rational value-decreasing mergers occur if the operating profit of the acquiring firm minus the price it paid for the target is lower than the acquiring firm's profit before the merger. This can happen if the synergies are large enough. In this case rivals will be worse off as well after the merger.

A prediction of the preemption theory is that when the acquiring firm loses value as a consequence of the transaction, the rivals should lose value as well. This prediction cannot be reconciled with the predictions of the earlier theories that tried to explain why value-decreasing mergers occur. If acquiring firms' managers are irrational and/or they are not maximizing the value of their firms this should benefit the rivals or at least leave them unaffected. The second part of this paper tests hypotheses that follow from the preemption theory, using a sample of 167 acquisitions between 1981-1998.

Five hypotheses are tested. Hypotheses 1 and 2, which follow from the simple value-

In his model, jump bidding signals high valuation and thus serves to preempt competition. In the model presented in this paper, jump bidding would make the rivals bid more aggressively because of the downstream competition. 
maximizing behavior of the managers of the acquiring firms, are that the value of the acquiring firms and the aggregate value of the merging firms should increase at the announcement of the merger. The aggregate value of the merging firms increases and the acquiring firms benefit from merger on average, but very often (around $50 \%$ of the sample) they incur substantial losses. The loss of the acquiring firm is inconsistent with the simple value-maximization assumption.

In contrast, the preemption model can explain why acquiring firms pursue takeovers that decrease their value. Hypothesis 3 is that, when the acquiring firm loses value, we should observe negative cumulative abnormal returns for the rivals around the announcement date. The results are, on average, consistent with this prediction. When acquiring firms lose, the rivals also suffer on average, since preemption will hurt the rival firms. More than $60 \%$ of the rivals in the sample had negative excess returns when the acquiring firms had negative excess returns. ${ }^{4}$ To explain why the other $40 \%$ had positive returns, a slight modification of the benchmark model called the "acquisition probability hypothesis" is introduced. Hypothesis 4 claims that mergers can signal future mergers that can increase the stock price of rivals who are expected to become future targets. In the sample approximately $20 \%$ of the rivals actually became targets later. Hypothesis 4 is tested in two subsamples. Rivals that become targets later have significantly positive cumulative abnormal return around the announcement date while rivals who do not become targets have significantly negative abnormal return. The results also suggest that the effect on rivals is not an overall negative industry shock but it is due to the merger.

Hypothesis 5 claims that the change in the aggregate value of the merging firms, which should depend only on the synergies of the merger, should be negatively correlated with the acquiring firms' abnormal returns. The results shows that the correlation indeed negative but it is not significant. This may be due to the under-estimation of the target firm's return or because our sample consists of rivals firms that were not strongly affected

\footnotetext{
${ }^{4}$ In the empirical finance literature there are papers by Eckbo (1983), Stillman (1983), Eckbo(1985), Eckbo and Wier (1985), and Eckbo (1992) examining the rivals' stock price reaction at merger announcement. These papers test that a horizontal merger is anticompetitive or not. If the announcement of a horizontal merger expected to increase the probability of successful collusion, or that eliminates one of the competitors of the price leader, the market would impound the resulting expected increase in the industry's monopoly rents in the market values of the merging firms' close competitors. All of these papers have rejected the collusion hypothesis in favor of the alternative hypothesis that horizontal mergers expected to generate productive efficiencies. Since they were interested in the antitrust implication of the mergers they do not consider the problem why value-decreasing mergers happen.
} 
by the merger.

The hubris and the agency models' empirical predictions are distinguishable from the predictions of the preemption model. If mergers happen because of managerial hubris or agency problems, rivals should be uniformly better off or at least unaffected when the stock price of the combined firms drop. The preemption model predicts that the rivals' stock price has to fall as well. In the sample the predictions of the hubris and agency models are rejected in favor of the preemption theory.

The Industrial Organization literature on mergers assumes that managers are rational and maximize the profit of shareholders. Under these assumptions this literature focuses upon the effect of mergers on product market competition, ex post profits, and welfare gains. Most of the early papers study a static oligopoly model to examine the incentives to merge in cases of either Cournot or Bertrand competition. Salant, Switzer, and Reynolds (1983) have found that in a symmetric Cournot model with linear demand and identical constant average cost, mergers are unprofitable as long as they do not encompass at least $80 \%$ of the market. ${ }^{5}$ The profits earned by the merged unit will be less than the sum of the profits of the merging partners before the merger. This occurs because merger participants do not capture all the profits that result from their merger. The contraction in output by the merged firm is offset by increased production of competitors. Deneckere and Davidson (1983) have shown that if firms engage in price competition and their product are differentiated, then mergers of any size are beneficial. Perry and Porter (1985) considered a more general market structure and asymmetric firms with different convex cost functions. They also found a stronger incentive to merge than Salant et al. (1983). Levin (1990) extends the Salant et al. (1983) analysis by relaxing the assumptions that the merged firm competes in a Cournot fashion even after the merger. Levin's results show that if firms with collective market shares of less than 50 percent merge, then any contraction of their output will cut their profits and increase welfare. Farrell and Shapiro (1990) provide a general model which contains the models by Salant et al.(1983), Perry and Porter (1985) and Levin (1990) as special cases. They prove that mergers can be privately profitable in a static Cournot market only if they generate synergies. ${ }^{6}$ The

\footnotetext{
${ }^{5}$ This number $(80 \%)$ is an artifact of Cournot competition with linear demand and constant marginal cost.

${ }^{6}$ Kamien and Zang (1990, 1991, 1993) and Gowrisankaran (1999) investigate the dynamics of the acquiring process and explore the interdependence between the mergers.
} 
second stage of the model presented in this paper is similar to Farrell and Shapiro (1990). They restrict their analysis to cases where acquirers do not lose. This paper shows that even if synergies are present and the merger is privately profitable, cases exist in which because of the preemptive motives, firms end up paying more for the target company than the increase in their profits in the post-merger market. Preemptive mergers can happen both in Cournot or Bertrand competition with differentiated product markets. This paper analyzes the case of Cournot competition in the downstream market.

The other line of research connected to the model of this paper is the preemptive patent licencing (see survey by Kamien (1992)) and auctions with externalities literature. Arrow (1962) discussed how the value of a patent on a cost-reducing innovation could depend on the underlying market structure (that is assumed to be either competitive or monopolistic). He found that licensing to a member of a downstream competitive industry yields more revenue than licensing to a monopolist. Gilbert and Newbery (1982) use an auction model to study whether a monopolist incumbent or a potential entrant is willing to pay more for an innovation. Their main result is that the monopolist will take into account the potential negative externalities of losing the auction and will pay more to preempt its rival. Papers which are most closely related to this paper are Kamien and Tauman $(1984,1986)$ and Katz and Shapiro $(1985,1986)$ who re-examine the results of Arrow in the case when the downstream industry is oligopolistic. They study several variations of a basic model which has the following structure: in the first stage the patentee decides the format of the procedure used to sell the licenses and the number of licenses he wants to sell. In the second stage firms decide simultaneously whether or not to purchase a license, and how much to bid for a license. In the third stage the firms in the oligopoly compete either through quantities or prices. The main result is that from the sellers point of view an auction dominates both fixed fee and royalties contracts. The model presented in this paper has a similar structure to these models, but the merger game is more complex than licensing. Mergers can have either positive or negative external effects on rivals depending on the size of the synergies. Because of that there is no symmetric pure strategy equilibrium in the model in this paper.

In all papers mentioned above, all relevant information is common knowledge for the participants. Jehiel and Moldovanu (2000) consider a bidding model with incomplete 
information where the outcome of the auction for a resource affects future downstream competition via a reduced-form "externality function," but they did not consider that information revealed through the bid can be used as signal that also can affect future interactions. Molnar (2000) considers the merger game with asymmetric information where bids can convey information. If after the auction, the information is still asymmetric, bids can influence the payoffs of the second stage game. Depending on whether the actions of the firms are strategic substitutes or complements in the second stage and on the format of the auction firms want to bid more or less than in the case of Jehiel and Moldovanu (2000). Because of signaling, the strategic equivalence between second-price and English auction does not hold. In the second-price sealed bid auction firms have incentives to increase (if products are strategic substitutes) their bids above their bid in the perfect information case because this not only increases the probability of winning but also increases the second stage payoff by making the rival less aggressive in the second stage. In the button version of the English auction, signaling is not possible because the auction stops when all but one bidder drops out. The winner's valuation will not be revealed because he pays the second highest price. In this case, rational bidders realize that increasing their bids increases the probability of winning but decreases their payoff in the second stage if they lose the auction (in case of strategic substitutes). Because of these effects in equilibrium second-price auction results in higher revenue than English auction if products are strategic substitutes.

This paper is organized as follows. In the first part of the paper, a simple two stage model is described to highlight the preemption motive in takeovers. Section 2 presents an example to motivate our analysis. In section 3.1, the equilibrium of market competition with equal synergies is analyzed. In section 3.2, the optimal bidding functions of the firm are derived. Section 4 extends the model to the case where synergies are not identical. In the second part of this paper, an event study is conducted to test the predictions of the preemption model. In a sample of 167 horizontal mergers between 1981-1998, the stock price reaction of the acquiring, target, and rival firms are examined. Section 5 describes the methodology and data of the event study used to test the hypotheses of the model. Section 6 summarizes the results, and section 7 concludes. 


\section{Motivation}

The events surrounding United Airlines recent takeover attempt of US Airways fit very well this paper's theory of preemptive mergers. On 23rd of May 2000 United Airlines announced a $\$ 4.3$ billion bid for US Airways. The parent company of United, UAL Corp. agreed to pay $\$ 60$ a share, a $130 \%$ premium, for the sixth-largest carrier on the domestic market. $^{7}$

The merger of United and US Airways seems like a perfect match. United is primarily an east-west airline, while US Airways primarily flies north-south routes. The newly merged company would have nearly twice as many flights as its nearest competitors. According to industry analysts and especially to the managers of UAL the acquisition of US Air is a logical step for UAL. "The US Airways route system fits very nicely with the United Airlines system." "If this deal goes through, it would turn the airline industry on its head." James E. Goodwin, chairman and chief executive officer of UAL Corporation, said "As the first carrier with a strong presence across the U.S., United will be positioned to provide a competitive challenge in new areas. We have the financial strength and unencumbered assets to continue to grow the company.... In short, United and US Airways together will create a more efficient global airline network that can improve the quality of service for its customers." ${ }^{8}$

On the day after the announcement, US Airways stock jumped $86 \%$ while UAL shares fell nearly $12 \%$. The loss to UAL was approximately $\$ 400$ million on that particular day.

Why did this happen? It appears that although the proposed merger is likely to create cost savings and improve efficiency, the premium that UAL offered to pay for US Airways was simply much larger than justified by synergies expected by the markets. So why United did enter into the arrangement?

The model presented in this paper suggests that if UAL fears that one of its rivals (e.g. American Airlines or Delta) will gain competitive advantage from taking over some third airline, then it is rational for UAL to preempt this merger with a takeover attempt of its own. This attempt can be optimal even if it requires UAL to overpay relative to the increase in the joint profits of the combined airlines. Even if the merger decreases

\footnotetext{
${ }^{7}$ See CNN. (http://cnnfn.com/2000/05/24/deals/united)

${ }^{8}$ Source: http://biz.yahoo.com/prnews/000524/il_united_.html
} 
profit flows compared to the original situation, it may increase profit flows compared to the relevant alternative rival merger.

The prediction of this paper's theory is that when the acquiring firm's stock falls, the stock values of the rivals should fall as well. In the case of the United-US Airways merger, the stock prices of UAL's two largest competitors - American (AMR Corp.) and Delta Airlines - dropped by $7.85 \%$ and $6.79 \%$ respectively. Meanwhile, less successful competitors' shares (potential targets), soared. American West increased by 18.4\%, Alaska Air by $5 \%$, TWA by $12.5 \%$, Northwest by $20 \%$.

According to analysts, the merger offer would spark a bidding war for US Airways or a takeover attempt of other carriers. The value of the smaller airlines increased, as investors tried to guess which airline might see the next offer. One analyst predicted that the winner probably would pay more than $\$ 60$ a share, while the loser would be left with a weaker position. "I see this as a lose-lose situation," he said. ${ }^{9}$ Analysts said that ultimately American's reaction depends on whether the airline believes the United-US Airways merger will go through.

\section{The model}

Consider three quantity-setting firms that produce a homogenous product. Let $P$ and $Q$ denote respectively the price and quantity in the market. Suppose that demand is given by

$$
P=a-Q
$$

Assume that, if no mergers occur, each firm has a constant marginal cost $c$ with no fixed costs. The subscript $N$ (for no merger) will be used to denote outcomes in the market if no merger occurs. Let $q_{N}$ denote the output per firm and $\pi_{N}$ denote the profit per firm. These are given by

$$
q_{N}=\frac{(a-c)}{4}
$$

\footnotetext{
${ }^{9}$ See CNN. (http://cnnfn.com/2000/05/24/deals/united)
} 


$$
\pi_{N}=\frac{(a-c)^{2}}{16}
$$

Suppose that two mergers are possible: either firm 1 can merge with firm 3 or firm 2 can merge with firm 3. In either case the merged firm would have marginal costs $c-s$ where $s \geq 0$. The parameter $s$ represents the level of cost synergies that result from the merger. The remaining firm would continue to have cost $c$. As will be explained below, it is assumed that firms 1 and 2 bid for the right to purchase firm 3 and the winner of the ensuing auction merges with firm 3. Therefore the subscript $w$ (for winner) will be used to denote values of the merged firm and the subscript $l$ (for loser) will be used to denote values of the other remaining firm in the resulting market equilibrium after a merger occurs. Let $q_{w}$ and $\pi_{w}$ denote, respectively, the output and profit of the merged firm if a merger occurs and let $q_{l}$ and $\pi_{l}$ denote similar values for the non-merged firm after the merger occurs. These are given by

$$
\begin{gathered}
\pi_{w}(s)=\left\{\begin{array}{ccc}
\frac{(a-c+2 s)^{2}}{9} & \text { if } & s \leq a-c \\
\frac{(a-c+s)^{2}}{4} & \text { otherwise }
\end{array}\right. \\
\pi_{l}(s)=\left\{\begin{array}{ccc}
\frac{(a-c-s)^{2}}{9} & \text { if } \quad s \leq a-c \\
0 & \text { otherwise }
\end{array}\right.
\end{gathered}
$$

In equations (4) and (5), when $s \leq a-c$, the cost advantage of the merged firm is small enough so that both firms survive in the resulting equilibrium. In contrast when $s \geq a-c$, the cost advantage of the merged firm is so large that in the resulting equilibrium, the non-merged firm exits the market.

The game unfolds in two steps. At the first step, firms 1 and 2 place bids to purchase firm 3 in a sealed bid second price auction. Firm 3 can accept one of the bids or decline them both. In the second stage the market opens and prices, quantities, and profits are determined as described above, depending upon whether or not a merger has occurred.

For ease of exposition, we assume that the bidding process is a second-price sealed-bid auction $^{10}$. According to the New Palgrave dictionary of Law and Economics (1998): "Under Delaware law (the predominant corporate law in the US), when a potential acquirer makes a serious bid for a target, the target's board of directors is required to act as would

\footnotetext{
${ }^{10}$ The second-price sealed-bids auction is strategically equivalent to the ascending auction for two bidders.
} 
'auctioneers charged with getting the best price for the stock-holders at a sale of the company." 11 Legislators assume that takeover auctions are similar to the classic English auction, which is efficient and generates high revenues. However, takeover auctions differ from the classic English auctions in several aspects. This paper will concentrate on one aspect which is the effect of the competition which follows the auction.

\subsection{Analysis}

It will be useful to begin by studying the functions $\pi_{w}(s)$ and $\pi_{l}(s)$. Assume that $s \leq a-c$ to rule out the situation where the market is monopolized. Figure 1 illustrates these functions. Recall that $\pi_{N}$ is the profit that a firm will earn in the three-firm Cournot equilibrium. The values of $\pi_{N}$ and $2 \pi_{N}$ are marked on the vertical axis since these are relevant comparison points for various calculations. These are equal to, respectively, $\frac{(a-c)^{2}}{16}$ and $\frac{(a-c)^{2}}{8}$.

Over the range $[0,(a-c)], \pi_{w}(s)$ is an increasing quadratic function that takes values between $\frac{(a-c)^{2}}{9}$ and $(a-c)^{2}$. Since $\pi_{w}(s)$ is less than $2 \pi_{N}$ at $s=0$ and greater than $2 \pi_{N}$ at $s=(a-c)$, there is a unique value of $s$ between these two values such that $\pi_{w}(s)=2 \pi_{N}$. Let $s$ denote this value. From (3) and (4), $s$ is approximately equal to $0.03(a-c) .{ }^{12}$

Now consider $\pi_{l}(s)$. From $(6), \pi_{l}(s)$ is a decreasing quadratic function over the interval $[0,(a-c)]$ that begins at the value $\frac{(a-c)^{2}}{9}$ and ends at the value 0 . Since $\pi_{l}(s)$ is greater than $\pi_{N}$ at $s=0$ and less than $\pi_{N}$ at $s=(a-c)$, there is a unique value of $s$ between these two values such that $\pi_{l}(s)=\pi_{N}$. Let $\bar{s}$ denote this value. From (3) and (5), $\bar{s}$ is equal to $\frac{(a-c)}{4}$. Note that $\bar{s}$ is greater than $s$. Figure 1 is drawn to reflect this fact.

\footnotetext{
${ }^{11}$ Cramton, P. (1998) "Auctions and Takeovers," in New Palgrave Dictionary of Law and Economics, Peter Neuman (ed.), London: MacMillan Press, 1. pp. 123

${ }^{12}$ Precisely $\underline{s}=\left(\frac{3 \sqrt{2}-4}{8}\right)(a-c)$.
} 
Figure 1: Gross Profits of Acquiring and Rival Firms

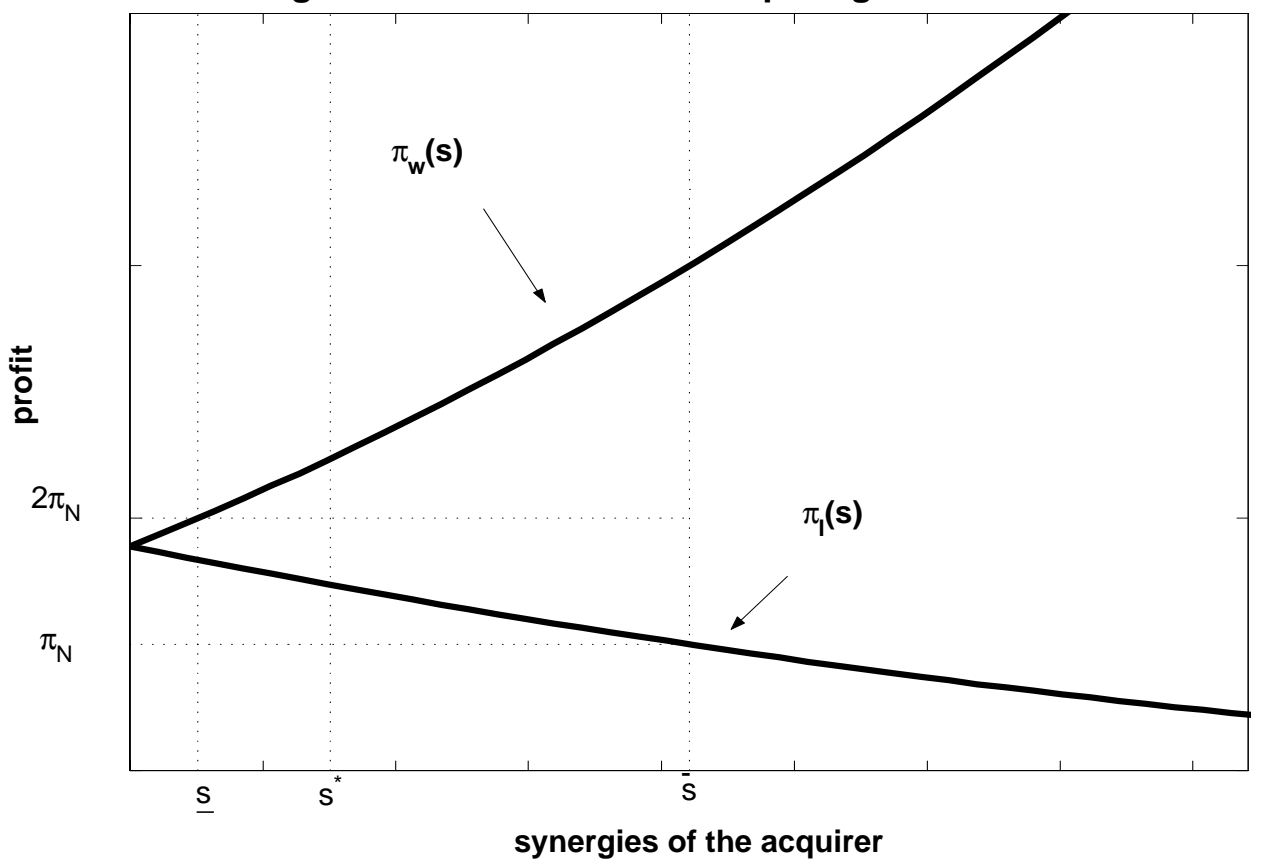

To interpret Figure 1, first consider the case where there are no cost synergies from the merger so that $s=0$. In this case the effect of the merger is simply to turn a three-firm symmetric oligopoly into a two-firms symmetric duopoly. The result is that the profit per firm goes up, although after the merger, the joint profits of the two merged firms are lower and the profit of the non-merged firm will be higher. ${ }^{13}$ As the level of cost synergies, $s$, begins to grow, another effect begins to play a role. After the merger, the merged firm becomes more efficient. This will increase the merged firm's profit but will decrease the rival firm's profit. For $s<s$, the synergy is small enough so that a merger decreases the joint profit of the merging firms and increases the profit of the rival firm. At $s$, the effect of $s$ is large enough so that the profit of the merged firms' is exactly equal the joint profits of the two firms if no merger occurs. At $s$, the rival firm is still better off under the merger.

Figure 1 also shows that at $s$, the rival firm gains a positive profit due to the reduction in market output. As $s$ grows above $s$, the gain of the merged firms increases and the gain of the non-merged firm decreases. At $\bar{s}$, the unmerged firm's gain is zero. Therefore, there must be a unique value of $s$ between $s$ and $\bar{s}$, denoted $s^{*}$, such that the joint gain of

\footnotetext{
${ }^{13}$ This is the result of Salant et. al. (1983)
} 
the merged firms is precisely equal to the gain of the non-merged firm. $s^{*}$ is determined implicitly by

$$
\pi_{w}(s)-2 \pi_{N}=\pi_{l}(s)-\pi_{N}
$$

Substitution of $(3)-(5)$ into (6) and reorganization yields that $s^{*}$ is approximately equal to $0.09(a-c) \cdot{ }^{14}$

The incentives of firm 1 and firm 2 to bid for firm 3 will be affected by the size of $s$. It turns out that three qualitatively different cases can be identified. When $s \leq s$, the merger of firms 1 or 2 with firm 3 will reduce the joint profit of the merged firms. Therefore there is no incentive for either to bid. When $s \leq s \leq s^{*}$, a merger would increase the joint profit of the merged firms but would increase the profit of the non-participating firm even more. Therefore, although both firms 1 and 2 would be willing to acquire firm 3 , there is a sense in which they would both rather "wait" for their rival to acquire firm 3. In this case the free rider problem arises as described by Stigler (1950). When $s \geq s^{*}$, the merged firms' joint profits increase by more than the non-participating firm. Therefore, there is a sense in which both firm 1 and firm 2 would prefer to purchase firm 3.

\subsection{Equilibrium of the bidding stage}

To find the optimal bid, suppose that firms 1 and 2 submit bids for firm 3 through a sealed-bid second price auction. Both firms can submit bids, and if at least one of the bids exceeds the reservation price, then the high bidder wins the target firm at the price of the second highest bid. In case they submit equal bids, then the seller will randomize and each firm can purchase the target with equal probability. The target board and managers face a constraint on their ability to set the reserve price, which is their legal duty to maximize the revenue to target shareholders. Here, for simplicity, assume that the reserve price is the target firm's initial profit, $\pi_{N}$.

If firm $i$ wins the auction, its payoff will be the profit of the more efficient combined firm $\left(\pi_{w}(s)\right)$ minus the price it has to pay for the takeover of the target. If firm $i$ loses the auction, its payoff will $\left(\pi_{l}(s)\right)$. If synergies for the acquiring firm are high enough $\left(s>\left(\frac{a-c}{4}\right)\right), \pi_{l}(s)$ is lower than the pre-merger profit.

\footnotetext{
${ }^{14}$ Precisely $s^{*}=\left(\sqrt{\frac{19}{16}}-1\right)(a-c)$.
} 
The dominant strategy is to bid the true value in this second price auction. Firm $i$ 's maximum willingness to pay for the target depends on the size of $s$. If $s<s$, the merger is unprofitable so the optimal bid is zero. If $s<s<\bar{s}$, the merger is profitable but it is even more profitable for the rival. The maximum bid will be equal to the reservation price and firms will mix between a zero bid and bidding the reserve price. If $\bar{s}<s$, the merged firm benefits more from mergers than the non-merging rival. In this case the maximum amount that it will be willing to pay is the profit in the case of winning the auction minus the profit if it loses. As $s$ increases, the profit of the non-merging firm decreases. The maximum amount that either will be willing to bid is increasing in $s$. If $\left(\frac{a-c}{4}\right)<s$, the profit of the non-merging firm is smaller then its original profit. Lemma 1 describes the pure strategy equilibria:

Lemma 1 There are two asymmetric pure strategy bidding equilibria. If $s \in[0, \underset{-}{0}]$, no merger will take place in equilibrium. If $s \in\left[s_{-}, s^{*}\right]$, firm 1 will always bid the reservation price and firm 2 will bid zero, or vice versa in the other equilibrium. If $s \in\left[s^{*}, c\right]$, both firms will bid $\pi_{w}(s)-\pi_{l}(s)$ in every equilibrium.

Proof. Assume that firm $j$ follows the above described bidding strategy. First consider the case when $s>s^{*}$. Bidding $\pi_{w}(s)-\pi_{l}(s)$ is a weakly dominant strategy. Any bid higher than this has a chance of winning the auction and paying a higher price than the value of merger for the bidder. Any bid lower than this has a chance of foregoing profitable takeover opportunities.

If $s<s<s^{*}$ and firm $j$ bids at or above the reserve price, then firm $i$ 's best response is to bid zero, since in this case the firm not winning the auction is better off. Given that firm $i$ 's bid is zero, firm $j$ cannot do any better than bid the reservation price and go through with the takeover.

If $s<s$, firms are not going to bid, since if they win they would be worse off than in the original situation.

Lemma 2 describes the mixed strategy equilibrium.

Lemma 2 The only symmetric equilibrium is a mixed strategy equilibrium. The equilibrium symmetric bidding strategies are similar to the asymmetric case if $s^{*}<s$ and if 
$s<s$. Within the region $s<s<s^{*}$ the bidders are mixing between bidding 0 or $\pi_{N}$ with probability $x(s)$ and $1-x(s)$ respectively. The equilibrium bidding strategies are:

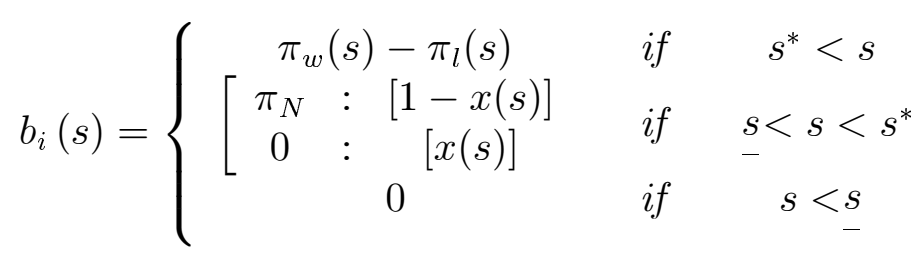

where $x(s)=\frac{\pi_{N}-\left(\pi_{w}(s)-\pi_{l}(s)\right)}{\pi_{w}(s)+\pi_{l}(s)-3 \pi_{N}}$.

Proof. Assume that firm $j$ follows the above bidding strategy. We show that in this case firm $i$ has no incentive to deviate from this strategy.

First consider the case where $s>s^{*}$, then $\pi_{w}(s)-\pi_{l}(s)>\pi_{N}$. Then bidding $\pi_{w}(s)-$ $\pi_{l}(s)$ is a weakly dominant strategy.

If $s<s<\bar{s}$, the mixed strategy equilibrium is bidding $\pi_{N}$ with probability $x(s)$. This probability makes firm $i$ indifferent between bidding $\pi_{N}$ or any lower amount. ${ }^{15}$ Bidding any higher amount would be unprofitable because then firm $i$ is better off if its rival wins $\left(\pi_{l}(s)>\pi_{w}(s)-\pi_{N}\right)$. Bidding strictly zero has a chance that no takeover happens which means that firm $i$ would forgo some profit opportunity $\left(\pi_{w}(s)>2 \pi_{N}\right)$.

If $s<\bar{s}$, firm $i$ is better off not winning. So it will bid zero.

Figure 2 illustrates the values of the firms after the merger. The losing firm's net value is $\pi_{l}(s)$. The winning firm's net value is its post-merger profit minus the price it pays for the target, $\left(\pi_{w}(s)-\max \left(\pi_{w}(s)-\pi_{l}(s), \pi_{N}\right)\right)$.

\footnotetext{
${ }^{15}$ The mixed strategy of firm $j$ (bidding 0 with probability $\mathrm{x}$ and bidding $\pi_{N}$ with probability 1 -x) has to make firm $i$ indifferent between bidding 0 or $\pi_{N}$ and vice versa: $\left(x+\frac{1-x}{2}\right)\left(\pi_{w}(s)-\pi_{N}\right)+\frac{1-x}{2} \pi_{l}(s)=$ $x \pi_{N}+(1-x) \pi_{l}(s)$.
} 
Figure 2: Net Profits of Acquiring and Rival Firms

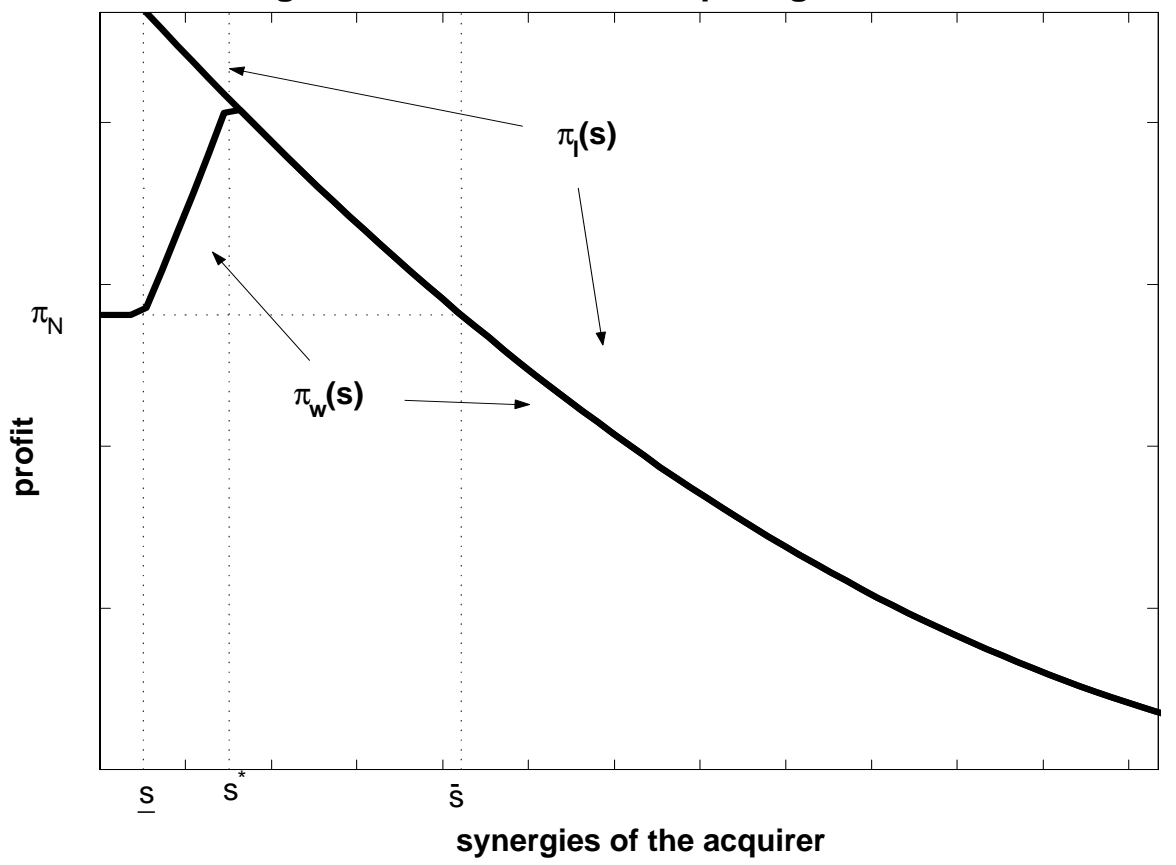

If $s<s$, no merger occurs and the net profits of the firms are the same as in the original situation, $\left(\pi_{N}\right)$. If $s \leq s \leq \bar{s}$ and mergers occur, the net value of the "losing" firm (denoted with solid line on the picture), is higher than the initial profit and decreases as the synergy increases. If $s>\bar{s}$, the "losing" firm's value after the merger is lower than before. The net value of the "winner" is increasing with the size of the synergy if $s \leq s \leq s^{*}$. If $s>s^{*}$ the net profit of the "winning" firm is decreasing in $s$ and, in the case of identical synergies, it is going to be to with the net profit of the "losing" firm. The reason for this is that in order to win the auction, the "winner" has to bid up to the value of the "losing" firm, which in this case is the same as the value of the "winner." If $s>\bar{s}$, both the "winner" and the "losing" firms end up worse off than they were before the merger.

Proposition 1 Rational value-decreasing mergers happen if firm $i$ wins the auction, and preempts its rival, but the post-merger profit of firm $i$ minus the price paid for the target is lower than the original profit. This can happen if $\bar{s}<s$.

Proof. Value-decreasing mergers mean, by definition, that the profit of the firm after merger minus the price paid for the target firm is lower than the original value of the firm, $\left(\pi_{w}(s)-\max \left(\pi_{w}(s)-\pi_{l}(s), \pi_{N}\right)<\pi_{N}\right)$. This condition simplifies to $\pi_{l}(s)<\pi_{N}$ when 
$s^{*}<s$ (otherwise $\pi_{w}(s)$ is always greater than $2 \pi_{N}$ if the merger occurs). As previously established, this condition holds if $\bar{s}<s$.

Corollary 1 If rational value-decreasing mergers take place, the value of the rival will also decrease.

If the synergies are the same and the firms are identical initially, the payoff is the same for both of them after the merger if $s>s^{*}$. If synergies are not symmetric, this will not be true as analyzed in the next section.

\section{Merger with asymmetric synergies}

This section considers the case where the potential acquiring firms can have different synergies $s_{1}$ and $s_{2}$. Assume that $s_{1}$ and $s_{2}$ are independently drawn from the uniform distribution on the interval $[0, c]$. Firms know each other's synergies but these are not known by the market or the target firm. The second stage Cournot game and the bidding strategies are similar to the symmetric synergy case.

\subsection{The bidding strategies of the firms if synergies are different}

If firm $i$ wins the auction, its payoff would be $\pi_{w}^{i}\left(s_{i}\right)$, minus the price it had to pay for the target. If firm $i$ loses the auction, its payoff would be $\pi_{l}^{i}\left(s_{j}\right)$. If synergies for the acquiring firm are high enough, this profit is lower than its pre-merger profit.

Firm $i^{\prime} s$ maximum bid cannot exceed the difference of the profits if it wins or if it loses. If both firms follow this strategy, then the price that the winner has to pay is equal to the difference in profits for the rival in case it wins or loses. If synergies are high enough, then mergers have negative externalities because the post-merger profits of the rivals will decrease. The following lemma shows that the equilibrium bidding strategy of this game is to bid exactly this difference.

Lemma 3 The pure strategy equilibrium bidding functions of the firms are,

$$
b_{i}\left(s_{i}, s_{j}\right)=\left\{\begin{array}{clc}
\pi_{w}^{i}\left(s_{i}\right)-\pi_{l}^{i}\left(s_{j}\right) & \text { if } & \pi_{w}^{i}\left(s_{i}\right)-\pi_{l}^{i}\left(s_{j}\right)>\pi_{N} \\
\pi_{N} \text { or } 0 & \text { if } & \pi_{N} \geq \pi_{w}^{i}\left(s_{i}\right)-\pi_{l}^{i}\left(s_{j}\right), \pi_{w}^{i}\left(s_{i}\right) \geq 2 \pi_{N} \\
0 & \text { if } & \pi_{w}^{i}\left(s_{i}\right)<2 \pi_{N}
\end{array}\right.
$$


Proof. Assume that firm $j$ follows the above bidding strategy. We show that in this case firm $i$ has no incentive to deviate from its strategy.

First consider the case when $\pi_{w}^{i}\left(s_{i}\right)-\pi_{l}^{i}\left(s_{j}\right)>\pi_{N}$. Bidding $\pi_{w}^{i}\left(s_{i}\right)-\pi_{l}^{i}\left(s_{j}\right)$ is a weakly dominant strategy. Any bid higher than this has a chance of winning the auction and paying a higher price than the value of the merger for the bidder. Any bid lower than this has a chance of foregoing profitable takeover opportunities.

If $\pi_{N} \geq \pi_{w}^{i}\left(s_{i}\right)-\pi_{l}^{i}\left(s_{j}\right)$ but $\pi_{w}^{i}\left(s_{i}\right) \geq 2 \pi_{N}$, and $\pi_{N} \geq \pi_{w}^{j}\left(s_{j}\right)-\pi_{l}^{j}\left(s_{i}\right)$ but $\pi_{w}^{j}\left(s_{j}\right) \geq 2 \pi_{N}$ one of the firms bids the reserve price and the other bids zero. Similarly to the case where synergies were equal, if this is the case then both firms are better off if the takeover occurs, but both firms are better off if the other is the acquiring firm. If one of them bids the reserve price, the other has no incentive to deviate. Bidding any higher than $\pi_{N}$ would be unprofitable because the firm is better off if its rival makes the takeover, $\left(\pi_{l}^{i}\left(s_{j}\right)>\pi_{w}^{i}\left(s_{i}\right)-\pi_{N}\right)$. Bidding anything less than $\pi_{N}$ when the rival does not bid has a chance that no takeover happens, which means that firm $i$ would be worse off, $\left(\pi_{w}^{i}\left(s_{i}\right)>2 \pi_{N}\right)$.

If $\pi_{w}^{i}\left(s_{i}\right)<2 \pi_{N}$, firm $i$ is better off not winning. So it will bid zero.

There is a mixed strategy equilibrium that is similar to the equal synergy case.

Lemma 4 In the mixed strategy equilibrium, there is mixing only if firms' synergies are in the range of $\pi_{N}>\pi_{w}^{i}\left(s_{i}\right)-\pi_{l}^{i}\left(s_{j}\right)$ but $\pi_{w}^{i}\left(s_{i}\right)>2 \pi_{N}$, and $\pi_{N}>\pi_{w}^{j}\left(s_{j}\right)-\pi_{l}^{j}\left(s_{i}\right)$ but $\pi_{w}^{j}\left(s_{j}\right)>$ $2 \pi_{N}$. In this case firm $i$ will not submit a bid with probability $x_{i}\left(s^{i}\right)=\frac{\pi_{l}^{i}\left(s_{j}\right)-\left(\pi_{w}^{i}\left(s_{i}\right)-\pi_{N}\right)}{\pi_{w}^{i}\left(s_{i}\right)+\pi_{l}^{i}\left(s_{j}\right)-3 \pi_{N}}$ and will submit a bid equal to the reserve price with probability $1-x_{i}\left(s^{i}\right)$.

Proof. The proof is similar to the proof of Lemma 2.

If for both firms, $\pi_{w}^{i}\left(s_{i}\right)-\pi_{l}^{i}\left(s_{j}\right)>\pi_{N}$, then firm $i$ can win the bidding if and only if:

$$
\pi_{w}^{i}\left(s_{i}\right)-\pi_{l}^{i}\left(s_{j}\right)>\pi_{w}^{j}\left(s_{j}\right)-\pi_{l}^{j}\left(s_{i}\right)
$$

This can be simplified to:

$$
\frac{2}{9}\left(s_{i}-s_{j}\right)\left(a-c+\frac{5}{9}\left(s_{i}+s_{j}\right)\right)>0 .
$$

This inequality holds only if $s_{i}>s_{j}$.

Industry profits are higher if the firm with the higher synergy wins. But because the winner has to make a payment to the target company, it is possible that its ex-post profit 
minus this price will be lower than its original profit. So the value of the combined firm will be lower than the sum of the values of its pre-merger its pieces.

Proposition 2 Rational value-decreasing mergers happen if firm $i$ wins the auction $\left(s_{i} \geqq\right.$ $s_{j}$ ) but the post-acquisition profit of firm $i$ minus the price paid for the acquisition is lower then the original profit was. i.e. $\pi_{w}^{i}\left(s_{i}\right)-\left(\pi_{w}^{j}\left(s_{j}\right)-\pi_{l}^{j}\left(s_{i}\right)\right) \leq \pi_{N}$.

Proof. The above expression can be simplified to the following inequality:

$$
7\left(\frac{a-c}{4}\right)^{2}+2\left(s_{i}-2 s_{j}\right)(a-c)+5 s_{i}^{2}-4 s_{j}^{2} \leq 0
$$

which is negative if

$s_{i} \leq-\left(\frac{a-c}{5}\right)+\frac{1}{20} \sqrt{\left(-19(a-c)^{2}+320 s_{j}\left(a-c+s_{j}\right)\right)}$

The above inequality will be satisfied for some parameter values. For example, suppose the demand function is $P=100-Q$, and the marginal cost of production $c=50$. The following graph illustrates when preemptive mergers can happen.

Figure 3: Payoff of merger if synergies are asymmetric

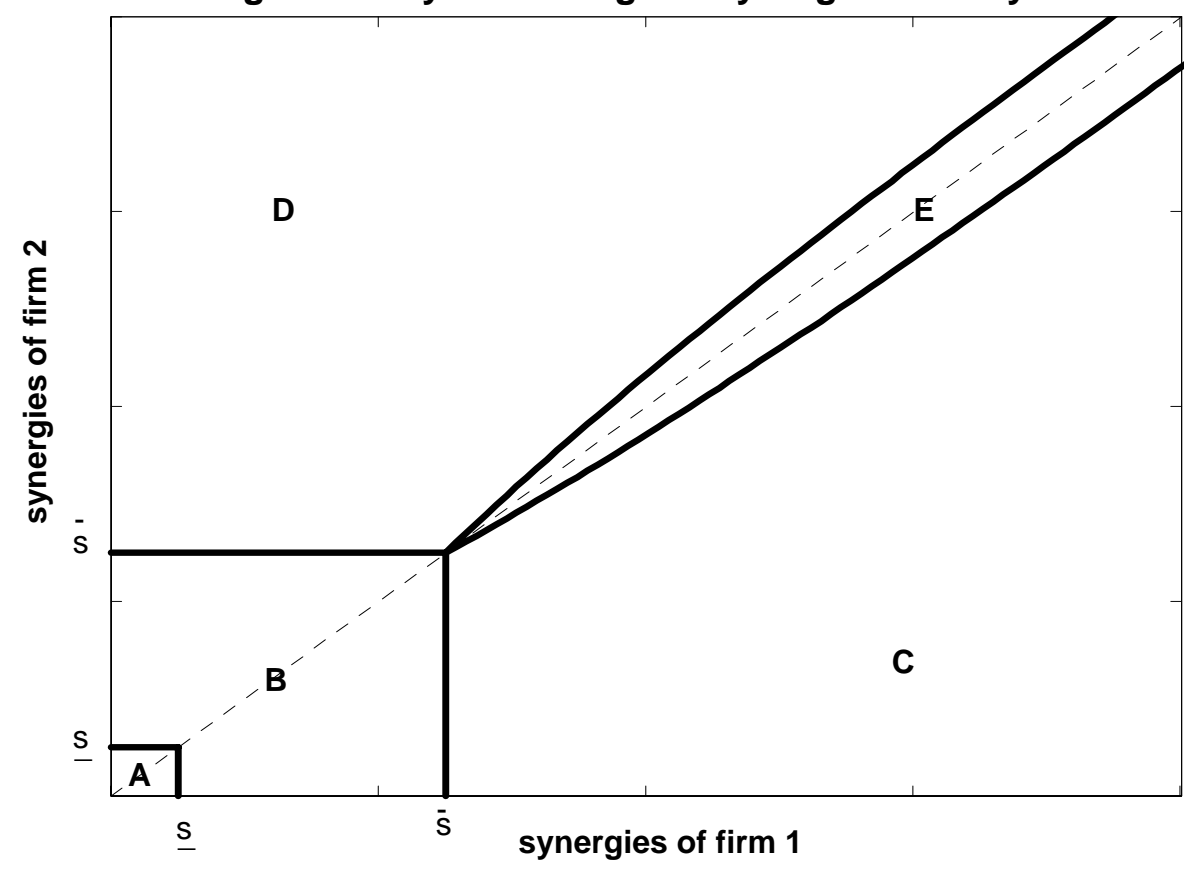

For given demand and cost parameters, the potential synergies can fully determine the post-merger payoffs of the acquiring and non-acquiring firms. The acquiring firm is always the firm with the higher synergies. So above the 45 degree line, the acquirer is always 
firm 1 and below it is always firm 2. In area $A$, no mergers happen. In area $B$ mergers are profitable and increase the rival's payoff as well. In areas $C$ and $D$, the acquirer's payoff increases but the rival's payoff falls. Finally, in area $E$, each firm's payoffs falls.

\section{Empirical tests of the Preemption Theory}

\subsection{Application of the model's prediction to stock market data}

In the previous sections, it was shown that under some circumstances, profit-maximizing managers pursue value-decreasing mergers to avoid even bigger losses. In this subsection, a brief discussion of the effect of these mergers on the stock prices of the acquirer and of the rival firms is used to motivate the empirical tests.

In the model, the profits of the firms if no merger occurs was compared to the profit's after the merger and it was found that profits after the merger can be lower than before. In the empirical test, it is assumed that the merger comes as a complete surprise so the pre-announcement prices reflect the no-merger profits. Mergers can convey several types of information. First, there is news that mergers can happen in the industry. Second, there is news concerning the identity of the merging parties. Third, mergers can signal future mergers, and cause revisions in the value of all firms in the industry. In terms of predicting stock price movements, the timing of the arrival of information is critical. For purposes of generating predictions to test the preemption theory, this paper assumes that all of this information is incorporated into stock prices in a short time period around the day of the announcement.

An unexpected takeover signals to the market that the acquisition was profitable compared to the opportunity cost for at least one firm in the industry. This leads to the revision of the valuation of every other firm competing in the same market. According to the preemption theory, if the acquiring firm's profit decreases, then the profit of the rivals should decrease as well. If the merger was unexpected, then the acquiring firm's stock price should fall as well as that of the rivals, holding everything else constant. However, the fact that the current merger has taken place changes the market expectations about future mergers. Rivals that are expected to be future targets could benefit from such expectations.

If the takeover is correctly anticipated then the abnormal return generated by the 
merger would be observed before the announcement since the market reacts only to the unexpected portion of the information. Partial anticipation of the acquisition would attenuate the observed abnormal returns at announcement. But since we can observe abnormal returns at the announcement date it seems that mergers are not fully expected and the announcement conveys information to the market.

\subsection{Testable implications of the theory}

Under the efficient markets/rational expectations hypothesis, stock prices reflect the combined effect of all changes in the firms' expected future cash flows. The cumulative abnormal stock returns measure the revisions of expectations of future performance. Merger related changes in product or factor prices change the expectation of future performance and so those changes should change the valuation to the bidder, target and rival firms competing in the same markets. Therefore the implications of the preemption theory are stated in terms of the observed cumulative abnormal returns of the related firms at the announcement date. Before formulating hypotheses based on this theory, it is important to state two implications of the standard neoclassical merger theory.

Hypothesis 1. Under the neoclassical assumptions (profit-maximizing and rationality), the combined value of the acquiring and the target firms increase at announcement.

This hypothesis follows under standard assumptions, in particular from the valuemaximizing behavior of the managers. Takeovers should be treated similarly to any other investment decision. Thus there should be a positive gain from the acquisition. This gain can be the result of either collusion or the prevalence of efficiencies.

The distribution of the gain however is a different question. It depends on the competitiveness of the takeover market. According to the collusion and the usual efficiency theories, regardless of the level of competition, the acquiring firm should at least break even. Negative abnormal returns are considered in the literature as evidence of the existence of non-value maximizing behavior by the management of acquiring firms. The simple preemption model presented in this paper predicts that the combined value of the firms should increase at the announcement of the merger. However, if we consider that submitting a bid can cost a significant amount of money (to hire consultants, investment bankers, etc.), preemption can also result in a decrease in the aggregate value of the 
merging companies.

Hypothesis 2. Under the neoclassical assumptions, the value of the acquiring firm doesn't decrease, on average, at the announcement of the merger. Hubris, agency and preemption theories predict that acquirers may suffer substantial losses.

The preemption theory, along with the efficiency theories, assumes value-maximizing behavior of the acquiring mangers but accounts also for the externalities created by the merger to the rivals. Because of these external effects, competition for the target firms is more fierce, and acquiring firms can sometimes "overpay" rationally. But since those external effects resulted from efficiencies, rivals firms should also be worse off after the takeover takes place.

Hypothesis 3. Preemption theory predicts that if the value of the acquiring firm decreases, then all else equal, the value of the rival firms should decrease as well.

The example of preemption theory described in this paper is a one shot game. More interesting cases would include the possibility of future mergers. Mergers can also signal future takeovers and future targets. Given that targets usually benefit from takeovers, the expectations of a rival firm being a future target can offset the negative effect of the current merger. Hypothesis 3 should hold only for rivals not expected to be future targets.

Hypothesis 4. The acquisition probability hypothesis predicts that if the acquiring firm's value decreases, then the observed abnormal return of the rivals should be related to the expectation of the rival being a future target.

According to the preemption theory, rivals are worse off because of the increased efficiency of the merged firms. The higher the gain of efficiency of the merged firms, the lower the rivals' return should be. Since the combined value of the merged entities should be only the function of efficiencies, it should be inversely correlated with the returns of those rivals that do not expect to be future targets. This conclusion also follows from agency theory, but for different reasons. According to agency theory, the loss of the aggregate value of the merging firm occurs because the managers maximize their own utility instead of the stockholders', and pay too much for the target firm. Consequently, the larger the loss in the total value, the larger the loss to the acquiring firm. A decrease in the value of the acquiring firm should not hurt the rivals.

Hypothesis 5. Under preemption theory, after controlling for rivals being future tar- 
gets, the rival firms' value should be inversely related to the change of the combined value of the acquiring and target firms.

According to the preemption theory, all five hypotheses should be true. According to collusion and the usual efficiencies theories, only hypotheses 1 and 2 should be true. According to non-value maximizing theories, such as hubris or agency theories, all hypotheses except 5 should be false. Table 1 contains a summary of the predictions of each model.

Table 1: Summary of the hypotheses.

\begin{tabular}{|l|l|l|}
\hline \hline & Return for acquirers & Return for rivals \\
\hline Collusion & positive & positive \\
\hline Efficiencies & positive & negative \\
\hline Efficiencies with "acquisition probability" & positive & positive for future targets \\
\hline Hubris and Agency & negative & positive or zero \\
\hline Preemption & if positive & either \\
\cline { 2 - 3 } & if negative & negative \\
\hline Preemption with "acquisition probability" & if negative & positive for future targets \\
\hline
\end{tabular}

\subsection{Methodology}

\subsubsection{Sample}

The data used to develop the acquisition sample was obtained from the Security Data Corporation (SDC) database, the CRSP (Center for Research in Security Prices) tapes, and Compustat. The preliminary sample included all mergers and acquisitions announced between 1981- 1998 where both the target and the acquiring firms were listed on either the New York (NYSE), American (AMEX) or Nasdaq Stock Exchange. The objective is to consider takeovers that could result in significant amount of synergies. Accordingly, only horizontal (within industry) mergers are considered. Mergers where the target and acquiring firms' primary four-digit SIC codes (reported by SDC) are identical are classified as horizontal mergers. In addition, the acquisition must have been accomplished in one transaction where the result was a 100\% ownership of the target. Acquisitions involving regulated firms such as banks, utilities and railroads are excluded. 
The rivals are also identified by the primary four-digit SIC codes from CRSP. All rivals must have been listed on either the New York (NYSE), American (AMEX) or Nasdaq Stock Exchange. The final sample contains 167 mergers with overall 2421 rival firms. The sample is smaller than the population mainly because of the requirement that both the target and the acquiring firms' and at least one rival firm's stock return should be available for the analysis. The average number of rivals for each merger is 14.5. Table 2 lists the number of horizontal acquisitions in the sample by year.

Table 2: Number of horizontal mergers in the sample by year (1981-1998)

\begin{tabular}{|ccccc|}
\hline \hline Year of the merger & Number of mergers & Number of rivals & Average number of rivals \\
\hline 1981 & 1 & 7 & 7 \\
1982 & 2 & 20 & 10 \\
1983 & 1 & 7 & 7 \\
1984 & 4 & 78 & 19.5 \\
1985 & 7 & 59 & 8.4 \\
1986 & 7 & 138 & 19.7 \\
1987 & 7 & 158 & 22.5 \\
1988 & 4 & 67 & 16.7 \\
1989 & 5 & 238 & 47.6 \\
1990 & 4 & 36 & 9 \\
1991 & 8 & 105 & 13.1 \\
1992 & 8 & 62 & 7.7 \\
1993 & 7 & 90 & 12.8 \\
1994 & 11 & 155 & 14.1 \\
1995 & 21 & 432 & 20.5 \\
1996 & 26 & 314 & 12.1 \\
1997 & 15 & 146 & 9.7 \\
1998 & 29 & 289 & 9.9 \\
\hline total & 167 & 2421 & 14.5 \\
\hline
\end{tabular}

\subsubsection{Estimation and Test Methodology}

The cumulative abnormal return of the acquiring, target, and rival firms are derived using an event study methodology. First, the expected share price without the merger is estimated using the market model. The market model is a statistical model that relates the return of any given security to the returns of the market portfolio. It assumes a 
stable linear relationship between the market and a stock's return. The model's linear specification follows from the assumed joint normality of asset returns

$$
R_{i, t}=\alpha_{i}+\beta_{i} R_{m, t}+\epsilon_{i, t}
$$

where $R_{i, t}$ is the actual return on security $i$ on day $t, R_{m, t}$ is the return on the market portfolio, and $\epsilon_{i, t}$ is the zero mean disturbance term. In this study the CRSP value weighted market index is used as the market portfolio.

As is standard in the literature, ordinary least squares estimation is conducted for each security in the sample, using 240 daily returns observation from day -300 to day -60 prior to the merger announcement. Under general conditions, ordinary least squares is a consistent estimation procedure for the market model parameters. Using the estimated parameters of the market model, abnormal returns were estimated in three event windows, $(-10,+10),(-5,+5)$ and $(-1,+1)$ around the announcement date. The announcement date is the first date when the merger was publicly announced according to SDC database.

In every time period, the abnormal return is the difference between the actual and the expected stock price without the merger:

$$
A_{i, t}=R_{i, t}-\hat{\alpha}_{i}-\hat{\beta}_{i} R_{m, t}
$$

where $\hat{\alpha}_{i}$, and $\beta_{i}$ are the OLS estimated parameters from the estimation period.

To draw inferences for the event, the abnormal return observations must be aggregated over time and across securities. First consider aggregation over time. Define the cumulative abnormal returns as the sum of the abnormal returns over the event window $[-l,+l]$. Given the daily abnormal returns, the measure of the acquiring, target and rival firms' performance were calculated as:

$$
C A R_{i,-l,+l}=\sum_{t=-l}^{+l} A_{i, t} .
$$

To test the null hypothesis that the cumulative abnormal returns are zero, t-statistics are calculated for $C A R_{i,-l,+l}$ by

$$
t_{i}\left(C A R_{i,-l,+l}\right)=C A R_{i,-l,+l} / \operatorname{std}\left(C A R_{i,-l,+l}\right)
$$

where $\operatorname{std}\left(C A R_{i,-l,+l}\right)$ is the standard deviation of $C A R_{i,-l,+l}$. 


\subsubsection{Independent variables}

To test our hypotheses, we need to control for the expectations of a rival being a future target. Song and Walkling (2000) have found that the cross-sectional variation of rival abnormal returns in the event window is systematically related to variables associated with the probability of acquisition. In their sample, target firms are significantly smaller and have a significantly lower level of Tobin's q than the other firms in the industry. Growth, block ownership, and leverage are insignificant. They also compared initial industry targets to rivals that become targets themselves within one year, and found none of these to be significant.

The firms total assets and Tobin's q were used as controls for the expectations of being a future target. All financial data were collected from Compustat using amounts from the fiscal year before the acquisition attempt on the initial target firm. Tobin's q was calculated as follows:

$$
Q=(M V+P+D-N W C) / T A,
$$

where $M V$ is the market value of equity calculated at the average market price of the shares out-standing in the fiscal year preceding the acquisition, $P$ is the liquidating value of preferred stock, $D$ is the book value of long-term debt, $N W C$ is net working capital, and $T A$ is the book value of total assets. Table 3 contains the summary statistics of the variables for the acquiring, target and rival firms.

Table 3: Summary statistics for the independent variables

\begin{tabular}{|c|c|c|c|c|}
\hline \hline & sample size & total asset (mill.\$) & Tobin's q & $M V$ (mill.\$) \\
\hline Acquiring firms & \multirow{2}{*}{167} & $\begin{array}{c}4035.926 \\
(11133.01)\end{array}$ & $\begin{array}{c}1.43 \\
(1.005)\end{array}$ & $\begin{array}{c}3209.67 \\
(7823.92)\end{array}$ \\
\hline Target firms & \multirow{2}{*}{167} & $\begin{array}{c}2055.214 \\
(15339.96)\end{array}$ & $\begin{array}{c}1.11 \\
(.7036)\end{array}$ & $\begin{array}{c}564.64 \\
(1379.16)\end{array}$ \\
\hline Rival firms & \multirow{2}{*}{2421} & $\begin{array}{c}2621.284 \\
(14033.54)\end{array}$ & $\begin{array}{c}1.435 \\
(1.637)\end{array}$ & $\begin{array}{c}1569.89 \\
(6439.34)\end{array}$ \\
\hline \multirow{2}{*}{ Rivals became target } & \multirow{2}{*}{496} & $\begin{array}{c}796.1822 \\
(2102.773)\end{array}$ & $\begin{array}{c}1.257 \\
(.9294)\end{array}$ & $\begin{array}{c}596.356 \\
(1646.06)\end{array}$ \\
\hline Rivals didn't become target & \multirow{2}{*}{1925} & $\begin{array}{c}3091.544 \\
(15668.22)\end{array}$ & $\begin{array}{c}1.481 \\
(1.772)\end{array}$ & $\begin{array}{c}1821.12 \\
(7153)\end{array}$ \\
\hline \multicolumn{2}{|c|}{ The brackets contain the standard deviations. } \\
\hline
\end{tabular}

In the sample, approximately $20 \%$ of the rivals became targets later and were delisted 
according to the CRSP. The results of Song and Walkling (2000) were reproduced but the explained variance of the data is still quite low. Because of that, a dummy variable for "future target" was included in the cross-sectional regressions, which has value one if the rival was delisted due to a merger and zero otherwise.

A dummy variable is introduced to measure the effect of all cash acquisitions where a value of one indicates all-cash, and a value of zero indicates cash and stock, all stock, and all other methods of payment for acquisitions. There is conflicting evidence in the empirical finance literature regarding the effect of different payment forms. Theoretically, the argument that all-cash acquisitions should outperform stock acquisition is given by Myers and Majluf (1984). The method of financing an investment can convey information. They argue that managers finance acquisitions by common stock because they think that the stock of the company is overvalued. Asymmetric information causes adverse selection. If a cash acquisition signals that the acquiring firm is undervalued (overvalued), this can lead to an increase (decrease) of the valuation of the whole industry. Jensen's free cash flow theory also supports the positive signal effect of cash payment. Cash acquisitions are usually financed with debt and they decrease the amount of free cash flow that can be invested by the management at below the cost of capital.

A study by Travlos (1987) analyzed the impact of payment form on both the target and the bidding firms. He found that when stock was used as a method of payment, bidders had significantly smaller and targets had significantly higher abnormal returns. Eckbo, Giammarino and Heinkel (1990) present evidence that bidder gains in Canada are on average the greatest when the bidder offers a mix of cash and stock. Queen (1989) considered the effect of a merger being anticipated, and she has found that while the form of payments has no effect on bidders, the average abnormal returns of the targets of non-cash acquisitions are higher in the pre-announcement period than for targets of cash acquisitions. She concluded that the predictive power of the form of payment is due to the inadequate analyses of expectations.

The method of payment, of course, can also reflect other factors such as the size of the target firm, interest rates, tax effects and the like. This can be expected to lead to conflicting results. In the sample, target firms involved in all cash acquisitions are significantly smaller than targets involved in acquisitions that were not all-cash. 


\subsection{Empirical Results}

\subsubsection{Aggregate results on acquisitions}

Table 4 shows the cumulative daily average abnormal returns to the acquiring, target and rival firms over 21 day, 11 day and 3 day periods, -10 through $+10,-5$ through +5 and -1 through +1 , relative to the day of the first press announcement of the acquisition, the t-statistics, and the percentage of firms with positive cumulative abnormal return.

Table 4: Cumulative average abnormal returns

\begin{tabular}{|c|c|c|c|c|c|}
\hline \multicolumn{6}{|c|}{ The size of event window } \\
\hline & Summ. stats. & $\mathrm{n}$ & $(-10,+10)$ & $(-5,+5)$ & $(-1,+1)$ \\
\hline Acquirers & $\begin{array}{l}\text { CAAR } \\
\text { t-stat. } \\
\text { positive }\end{array}$ & 167 & $\begin{array}{c}-1.49 \% \\
(-1.50) \\
0.47\end{array}$ & $\begin{array}{c}-0.85 \% \\
(-1.09) \text {. } \\
0.45\end{array}$ & $\begin{array}{c}+0.06 \% \\
(+0.10) \\
0.50\end{array}$ \\
\hline Targets & $\begin{array}{l}\text { CAAR } \\
\text { t-stat. } \\
\text { positive }\end{array}$ & 167 & $\begin{array}{c}+25.83 \%{ }^{* * *} \\
(12.60) \\
0.86\end{array}$ & $\begin{array}{c}+24.18 \% \%^{* * *} \\
(12.06) \\
0.86\end{array}$ & $\begin{array}{c}+21.13 \% \%^{* * *} \\
(11.54) \\
0.79\end{array}$ \\
\hline Rivals & $\begin{array}{l}\text { CAAR } \\
\text { t-stat. } \\
\text { positive }\end{array}$ & 2421 & $\begin{array}{c}-0.83 \%^{* *} \\
(-2.29) \\
0.46\end{array}$ & $\begin{array}{c}-0.18 \% \\
(-0.66) \\
0.47\end{array}$ & $\begin{array}{c}+0.56 \% \text { \%** } \\
(3.22) \\
0.49\end{array}$ \\
\hline *, $* *, * * *$ & . & a & 507 & spectiv & \\
\hline
\end{tabular}

The mean return to acquirers is mostly non-significant. As the event window is expanded, the returns to acquiring firms deteriorate. Also, in the 1990s, the excess return of the acquiring firms drops dramatically. In the period 1991-1998, the excess return of the acquiring firms is a statistically significant $-4.07 \%$. Stockholders of the target on the other hand, realize on average an abnormal return of nearly $25 \%$, and these are probably understated. Expectations and insider trading can cause an earlier price run-up. This is consistent with the fact that as the event window is expanded, the returns to target firms increase. While there is little doubt on average that the target firms benefit from mergers, the effect on rival firms is ambiguous. Over the shorter time period, rivals have a small but significant positive abnormal return, but as the time period increases, the cumulative average abnormal return becomes negative.

These results are consistent with most of the other studies conducted on mergers and 
acquisitions. ${ }^{16}$ Table 5 shows the average aggregate abnormal change in the market value of the acquiring and target firms. ${ }^{17}$

Table 5: Abnormal change in the aggregate value of the merging firms.

\begin{tabular}{|c|c|c|c|c|c|}
\hline & & & \multicolumn{3}{|c|}{ The size of event window } \\
\hline & Summ. stats. & $\mathrm{n}$ & $(-10,+10)$ & $(-5,+5)$ & $(-1,+1)$ \\
\hline $\begin{array}{c}\text { Change in the total } \\
\text { value of acquiring } \\
\text { and target firms }\end{array}$ & $\begin{array}{l}\text { CAAR } \\
\text { t-stat. } \\
\text { positive }\end{array}$ & 167 & $\begin{array}{c}+4.47 \% * * * \\
(4.292) \\
0.64\end{array}$ & $\begin{array}{c}+4.5 \% \text { *** } \\
(5.409) \\
0.62\end{array}$ & $\begin{array}{c}+4.36 \% \text { *** } \\
(6.776) \\
0.69\end{array}$ \\
\hline
\end{tabular}

Table 5 supports the concept of value maximizing takeovers. Hypothesis 1 holds on average. The combined value of the merging firms increases by a significant $4-5 \%$ in all examined time periods around the announcement date. However one-third of the mergers have negative aggregate gain. Even in these cases, preemption theory is not necessarily false. Preemptive mergers can also decrease the total value of the firms if the acquisition process involves high costs.

Hypothesis 2, which says that acquirers do not lose on average, also cannot be rejected. Acquirors' abnormal return on the average is insignificant. However, in more than $50 \%$ of the cases, the shareholders of the acquiring firms suffer losses. This fact contradicts the usual value-maximizing theories, but is in accord with the agency, hubris, and preemption theories. The significantly positive abnormal performance of the target firms in response to the merger announcement indicates that the announcement comes at least partially as a surprise.

To separate the predictions of the preemption theory from the non-value maximizing theories hypothesis 3 is tested. Following the discussion about the predictions of preemption theory, one expects that rivals should have a negative abnormal return fol-

\footnotetext{
${ }^{16}$ Schwert (1996) has found that acquiring firms' abnormal returns were not significantly different from zero on average for the period 1975-1991, while targets enjoy a hefty $30-40 \%$ excess return in the same period. Jarrell, Brickley and Netter (1988) have found a steady decrease in the returns to shareholders of the acquiring companies for a sequence of decades from the 1960s to the 1980s. They found that for the 1980s, the excess return of acquiring firms became negative 1\%, but remained statistically insignificant. Jensen and Ruback (1983) estimated zero returns to the acquiring firms in mergers.

${ }^{17}$ The average aggregate abnormal change in the market value of the acquiring and target firms is calculated as the value-weighted sum of the abnormal returns of target and acquiring firms.
} 
Table 6: Cumulative average abnormal returns if the acquiring firm has negative cummulative abnormal return

\begin{tabular}{|c|c|c|c|c|c|c|c|}
\hline \multicolumn{8}{|c|}{ The size of the event window } \\
\hline & Summ. stats. & $\mathrm{n}$ & $(-10,+10)$ & $\mathrm{n}$ & $(-5,+5)$ & $\mathrm{n}$ & $(-1,+1)$ \\
\hline Acquirer & $\begin{array}{l}\text { CAAR } \\
\text { t-stat. } \\
\text { positive }\end{array}$ & 88 & $\begin{array}{c}-10.71 \%^{* * *} \\
(-12.59) \\
0\end{array}$ & 93 & $\begin{array}{c}-7.33 \%^{* * *} \\
(-10.64) \\
0\end{array}$ & 83 & $\begin{array}{c}-4.99 \%^{* * *} \\
(-9.06) \\
0\end{array}$ \\
\hline Target & $\begin{array}{l}\text { CAAR } \\
\text { t-stat. } \\
\text { positive }\end{array}$ & 88 & $\begin{array}{c}+23.18 \% \%^{* * *} \\
(+7.34) \\
0.81\end{array}$ & 93 & $\begin{array}{c}+20.21 \% \text { *** } \\
(+8.38) \\
0.81\end{array}$ & 83 & $\begin{array}{c}+20.04 \% \text { *** } \\
(+6.76) \\
0.80\end{array}$ \\
\hline Rivals & $\begin{array}{l}\text { CAAR } \\
\text { t-stat. } \\
\text { positive }\end{array}$ & 1340 & $\begin{array}{c}-1.69 \%^{* * *} \\
(-3.49) \\
0.40\end{array}$ & 1474 & $\begin{array}{c}-1.20 \%^{* * *} \\
(-3.47) \\
0.43\end{array}$ & 1299 & $\begin{array}{c}+0.33^{*} \\
(1.3414) \\
0.48\end{array}$ \\
\hline
\end{tabular}

lowing value-decreasing mergers. Table 6 summarizes the results for the subsample where the acquiring firm had a negative excess return. Table 7 summarizes the results for the subsample where the acquiring firms had positive excess returns.

Table 7: Cumulative average abnormal returns if the acquiring firm has positive cummulative abnormal return

\begin{tabular}{|c|c|c|c|c|c|c|c|}
\hline \multicolumn{8}{|c|}{ The size of the event window } \\
\hline & Summ. stats. & $\mathrm{n}$ & $(-10,+10)$ & $\mathrm{n}$ & $(-5,+5)$ & $\mathrm{n}$ & $(-1,+1)$ \\
\hline Acquirer & $\begin{array}{l}\text { CAAR } \\
\text { t-stat. } \\
\text { positive }\end{array}$ & 79 & $\begin{array}{c}+8.79 \%^{* * *} \\
(+9.11) \\
1\end{array}$ & 74 & $\begin{array}{c}+7.30 \%^{* * *} \\
(+8.911) \\
1\end{array}$ & 84 & $\begin{array}{c}+5.01 \%^{* * *} \\
(+7.068) \\
1\end{array}$ \\
\hline Target & $\begin{array}{l}\text { CAAR } \\
\text { t-stat. } \\
\text { positive }\end{array}$ & 79 & $\begin{array}{c}+28.79 \%^{* * *} \\
(+11.47) \\
0.899\end{array}$ & 74 & $\begin{array}{c}+29.19 \%^{* * *} \\
(+8.8769) \\
0.919\end{array}$ & 84 & $\begin{array}{c}+22.22 \%^{* * *} \\
(+10.20) \\
0.916\end{array}$ \\
\hline Rivals & $\begin{array}{l}\text { CAAR } \\
\text { t-stat. } \\
\text { positive }\end{array}$ & 1081 & $\begin{array}{c}+0.227 \% \\
(0.42) \\
0.528\end{array}$ & 947 & $\begin{array}{c}+1.42 \%^{* * *} \\
(+3.25) \\
0.522\end{array}$ & 1122 & $\begin{array}{c}+0.82 \%^{* * *} \\
(+3.45) \\
0.48\end{array}$ \\
\hline
\end{tabular}

From Table 6 it is apparent that following value-decreasing horizontal mergers, nonmerged firms are systematically earning negative abnormal returns. This is consistent with the prediction of the preemption theory but inconsistent with the predictions of the agency and hubris theories. Results from Tables 6 and 7, are inconsistent with the hypothesis that the rivals' excess returns are the same regardless of the acquiring firm's 
return, at every significance level for the $(-10,+10)$ event window. In the whole sample, the hypothesis that the rivals' mean abnormal return, when the acquiring firm has negative abnormal return, is the same as the rivals' mean abnormal, can be rejected at a $10 \%$ significance level.

The magnitude of the numbers is remarkable. The average loss of the acquiring firms is $\$ 238.29$ million while the rivals lose $\$ 29.12$ million dollars over the $[-10,+10]$ time period around the announcement. ${ }^{18}$

While on average the results in Table 6 support hypothesis 3, in more than one-third of the cases rivals actually benefit from takeovers when the acquiring firms suffer losses. This fact again does not necessarily mean the failure of preemption theory in those cases. The simple static model presented in the first part of this paper doesn't account for the dynamics of the merger market. In particular, it doesn't account for expectations. A merger can signal several things about the target, acquiring, and rival firms. Song and Walkling (2000) develop and test one possible implication of takeovers. They find that $50-60 \%$ of the rivals earn positive abnormal returns. ${ }^{19}$ Their explanation is that the rivals earn abnormal returns because of the increased probability that they will be targets themselves. They show that rivals that become targets in subsequent years are significantly smaller, have significantly smaller Tobin's qs, and earn significantly larger abnormal returns at the initial acquisition announcement than other rivals.

Table 8 shows the cumulative average abnormal returns of rival firms if the rival becomes a target later, and if it does not. Similarly to Song and Walkling's results, Table 8 indicates that the market forms some expectations about the identity of future targets based on the current takeover. Rivals that subsequently become targets enjoy significant positive return over the period of $(-10,+10)$ and $(-1+1)$ and rivals that don't become future target suffer a significant loss over the period of $(-10,+10)$ and $(-5,+5) .{ }^{20}$

To test hypothesis 5 , one needs to calculate the change in the aggregate value of the

\footnotetext{
${ }^{18}$ The value of the firms before the merger calculated as a product of the shares out-standing (from Compustat) and the stock price before the announcement.

${ }^{19}$ Their sample consisted of 141 unexpected acquisitions and 2459 rival firms over the 1982-1991 period. Their sample consisted of both horizontal and non-horizontal mergers. They report that the abnormal returns to a portfolio of rivals average a significant $0.35 \%$ for the announcement period $(-1,0)$ and a significant $0.56 \%$ over the expanded $(-5,+5)$ event window. This is similar to the finding of this paper. They didn't examine the effect of the acquiring firms' return on the rivals' returns.

${ }^{20}$ At $5 \%$ significance level.
} 
Table 8: Cumulative average abnormal returns of rival who became and rivals who did not become future targets if the acquiring firm has negative cummulative abnormal return

\begin{tabular}{|c|c|c|c|c|c|c|c|}
\hline \multicolumn{8}{|c|}{ The size of event window } \\
\hline & Summ stats. & $\mathrm{n}$ & $(-10,+10)$ & $\mathrm{n}$ & $(-5,+5)$ & $\mathrm{n}$ & $(-1,+1)$ \\
\hline $\begin{array}{l}\text { Rivals which } \\
\text { didn't become } \\
\text { targets later }\end{array}$ & $\begin{array}{l}\text { CAAR } \\
\text { t-stat. } \\
\text { positive }\end{array}$ & 1081 & $\begin{array}{c}-2.60 \%^{* * *} \\
(-4.9102) \\
0.38\end{array}$ & 1144 & $\begin{array}{c}-1.30 \%^{* * *} \\
(-3.2883) \\
0.42\end{array}$ & 1018 & $\begin{array}{c}-0.026 \% \\
(-0.114) \\
0.47\end{array}$ \\
\hline $\begin{array}{c}\text { Rivals which } \\
\text { became targets } \\
\text { later }\end{array}$ & $\begin{array}{l}\text { CAAR } \\
\text { t-stat. } \\
\text { positive }\end{array}$ & 259 & $\begin{array}{c}+2.115 \%^{* *} \\
(1.8364) \\
0.46\end{array}$ & 330 & $\begin{array}{c}-0.875 \% \\
(-1.20) \\
0.46\end{array}$ & 135 & $\begin{array}{c}+1.65 \%^{* *} \\
(+2.05) \\
0.494\end{array}$ \\
\hline
\end{tabular}

merged firms. To estimate the initial stock market value of the firms, the average of the closing price and the shares outstanding from the calendar year before the announcement of the merger were used. The change in the total value of the acquiring firms was calculated as the value weighted sum of the target and the acquiring firms' cumulative abnormal returns. Table 9 summarizes the correlations between the rivals' cumulative average abnormal returns and the merging firm's aggregate abnormal return where the merging firm's aggregate abnormal returns are positive and the acquiring firm has a negative excess return. ${ }^{21}$

Table 9: Correlations between the aggregate cumulative abnormal returns of rivals and merging firms in different event windows.

\begin{tabular}{|c|c|c|c|c|c|c|}
\hline \hline & rCAAR10 & rCAAR5 & rCAAR1 & tCAAR10 & tCAAR5 & tCAAR1 \\
\hline rCAAR10 & 1.00 & \multicolumn{7}{l|}{} \\
\hline rCAAR5 & 0.7675 & 1.00 & & & \\
\hline rCAAR1 & 0.8038 & 0.6075 & 1.00 & & \\
\hline tCAAR10 & -0.0225 & -0.0653 & 0.0228 & 1.00 & & \\
\hline tCAAR5 & -0.0072 & -0.0225 & 0.0309 & 0.6645 & 1.00 & 1.00 \\
\hline tCAAR1 & -0.0093 & -0.0494 & 0.0198 & 0.8816 & 0.7370 & \\
\hline $\begin{array}{l}\text { "rCAAR" denotes the rivals' average cumulative abnormal return. "tCAAR" denotes the } \\
\text { value-weighted sum of the acquiring and target firms' average cumulative abnormal returns. }\end{array}$ \\
\hline
\end{tabular}

Results in Table 9 do not provide strong support for the preemption theory, although they do not reject it. The correlation between the rivals' and the merging firms' aggregate

\footnotetext{
21 "rCAAR" denotes the rivals' average cumulative abnormal return. "tCAAR" denotes the valueweighted sum of the acquiring and target firms' average cumulative abnormal returns.
} 
Table 10: Estimated regression coefficients of the $(-10,+10)$ announcement period abnormal returns of rivals. (t-statistics are given in parentheses) Dependent Variable= rivals' returns in $(-10,+10)$ event window. Acq. CAAR is the acquiring firms abnormal return, future target is a dummy variable with a value of 1 if the rival become target later, $\mathrm{r}$ _tta is the ratio of the rival's and target's total assets, r_tq is the ratio of the rival's and target's Tobin's q, cash is a dummy with a value of 1 if the merger was all-cash merger, nriv is the number of rivals.

\begin{tabular}{|ccccccc|}
\hline \hline & model 1 & if acar $<0$ & if acar $>0$ & model 2 & if acar $<0$ & if acar $>0$ \\
\hline \multirow{2}{*}{ const } & -0.0004 & .007857 & -0.02513 & 0.0053 & +0.0034 & +0.0202 \\
& $(-0.046)$ & $(0.98)$ & $(-0.981)$ & $(0.303)$ & $(0.191)$ & $(0.621)$ \\
acq. CAAR & $+0.178^{* * *}$ & $+0.191^{* * *}$ & $+0.419^{* * *}$ & $+0.14^{* * *}$ & $+0.212^{* * *}$ & $+0.221^{* *}$ \\
& $(3.674)$ & $(2.513)$ & $(2.662)$ & $(2.389)$ & $(2.419)$ & $(2.161)$ \\
future target & & & $+0.043^{* * *}$ & $+0.050^{* * *}$ & $+0.034^{* * *}$ \\
& & & $(4.23)$ & $(3.86)$ & $(2.580)$ \\
r_tta & & & -0.00046 & $-0.0011^{*}$ & +0.0013 \\
& & & $(-0.98)$ & $(-1.79)$ & $(1.583)$ \\
r_tq & & & -0.00104 & $-0.0079^{*}$ & +0.0057 \\
& & & $(-0.22)$ & $(-1.69)$ & $(0.645)$ \\
cash & & & +0.02974 & +0.016 & $+0.0507^{*}$ \\
& & & & $(1.53)$ & $(1.39)$ & $(1.718)$ \\
time & & & & +0.00052 & +0.0011 & -0.0028 \\
& & & & $-0.467)$ & $(0.835)$ & $(-1.604)$ \\
nriv & & & & $-0.0013^{*}$ & -0.0003 & $-0.0022^{* *}$ \\
& & & & $-1.707)$ & $(-1.133)$ & $(-1.95)$ \\
\hline$R^{2}$ & 0.012 & 0.01 & 0.0304 & 0.0413 & 0.026 & 0.0945 \\
\hline
\end{tabular}

mean excess returns is, at best, insignificant. In the whole sample it is positive. This can be due to the under-estimation of the targets' returns and/or due to that the sample includes several firms that were actually not related, and so unaffected by the merger.

\subsubsection{Cross-sectional regression results}

This subsection reports in detail the cross sectional results for the test of hypotheses 3 and 4. For each of the three event window result for two model specification is presented. In Tables 10 through 12 we regress announcement period abnormal returns of the rivals' on abnormal returns of the acquiring firms, firm characteristics associated with the probability of acquisition, and characteristics of the specific deal for all three event windows discussed above.

The observations of rivals' returns are independent across mergers, but not necessarily independent within a merger. Because of this reason, the standard errors from OLS esti- 
Table 11: Estimated regression coefficients of the $(-5,+5)$ announcement period abnormal returns of rivals. (t-statistics are given in parentheses) Dependent Variable $=$ rivals' return in $(-5,+5)$ event window. Acq. CAAR is the acquiring firms abnormal return, future target is a dummy variable with a value of 1 if the rival become target later, r_tta is the ratio of the rival's and target's total assets, $\mathrm{r}$ tq is the ratio of the rival's and target's Tobin's q, cash is a dummy with a value of 1 if the merger was all-cash merger, nriv is the number of rivals.

\begin{tabular}{|ccccccc|}
\hline \hline & model 1 & if acar5<0 & if acar5 $>0$ & model 2 & if acar5<0 & if acar5>0 \\
\hline \multirow{2}{*}{ const } & $+0.00685^{*}$ & $+0.0211^{* * *}$ & $+0.012^{*}$ & +0.0147 & $+0.045^{* *}$ & -.0139 \\
& $(1.661)$ & $(3.120)$ & $(1.63)$ & $(1.12)$ & $(2.549)$ & $(-0.697)$ \\
acq. CAAR5 & $+0.21^{* * *}$ & $+0.376^{* * *}$ & +0.0768 & $+0.182^{* * *}$ & $+0.32^{* * *}$ & +0.0615 \\
& $(3.155)$ & $(2.993)$ & $(1.365)$ & $(4.280)$ & $(3.858)$ & $(1.191)$ \\
future target & & & $+0.021^{* *}$ & +0.0083 & $+0.049^{* * *}$ \\
& & & $(2.33)$ & $(0.909)$ & $(2.59)$ \\
r_tta & & & $-0.001^{* * *}$ & $-0.0013^{* * *}$ & -0.00011 \\
& & & $(-3.155)$ & $(-3.006)$ & $(-0.281)$ \\
r_tq & & & -0.0017 & -0.001 & -0.0034 \\
& & & $(-0.66)$ & $(-0.358)$ & $(-0.742)$ \\
cash & & & +0.0086 & +0.012 & +0.00145 \\
& & & $(0.941)$ & $(1.043)$ & $(0.139)$ \\
time & & & +0.00029 & -.00084 & $+0.0025^{* *}$ \\
& & & & $(0.376)$ & $(-0.828)$ & $(2.306)$ \\
nriv & & & -0.00057 & -0.0007 & -0.00034 \\
& & & & $(-1.505)$ & $(-1.520)$ & $(-1.595)$ \\
\hline$R^{2}$ & 0.021 & 0.029 & 0.002 & 0.0324 & 0.0413 & 0.0284 \\
\hline
\end{tabular}


Table 12: Estimated regression coefficients of the $(-1,+1)$ announcement period abnormal returns of rivals. (t-statistics are given in parentheses) Dependent Variable $=$ rivals' return in $(-1,+1)$ event window. Acq. CAAR is the acquiring firms abnormal return, future target is a dummy variable with a value of 1 if the rival become target later, r_tta is the ratio of the rival's and target's total assets, $\mathrm{r}$ tq is the ratio of the rival's and target's Tobin's q, cash is a dummy with a value of 1 if the merger was all-cash merger, nriv is the number of rivals.

\begin{tabular}{|ccccccc|}
\hline \hline & model 1 & if acar1<0 & if acar1 $>0$ & model 2 & if acar1<0 & if acar1>0 \\
\hline \multirow{2}{*}{ const } & $+0.007^{* * *}$ & $+0.013^{* * *}$ & +0.0039 & +0.0057 & +0.0136 & +0.0012 \\
& $(3.512)$ & $(3.309)$ & $(1.324)$ & $(0.924)$ & $(1.480)$ & $(0.138)$ \\
acq. CAAR1 & $+0.10^{* * *}$ & $+0.17^{* * *}$ & $+0.12^{* * *}$ & $+0.098^{* * *}$ & $+0.162^{* * *}$ & $+0.11^{* * *}$ \\
& $(3.97)$ & $(2.95)$ & $(3.48)$ & $(4.094)$ & $(3.858)$ & $(4.239)$ \\
future target & & & $+0.021^{* * *}$ & $+0.02^{*}$ & $+0.022^{* * *}$ \\
& & & $(3.165)$ & $(1.91)$ & $(2.659)$ \\
r_tta & & & $-0.00066^{* * *}$ & $-0.00068^{* *}$ & $-0.00064^{* * *}$ \\
& & & $(-3.365)$ & $(-2.012)$ & $(-3.021)$ \\
r_tq & & & $-0.0027^{* *}$ & -0.00182 & $-0.0049^{* * *}$ \\
& & & $(-1.932)$ & $(-0.993)$ & $(-2.564)$ \\
cash & & & +0.0047 & +0.00045 & +0.0063 \\
& & & $(1.232)$ & $(0.071)$ & $(1.437)$ \\
time & & & +0.00034 & +0.000008 & $+0.00077^{*}$ \\
& & & & $0.819)$ & $(0.011)$ & $(1.680)$ \\
nriv & & & -0.00014 & -0.00004 & $-0.000207^{* * *}$ \\
& & & & $(-1.486)$ & $(-0.309)$ & $(-2.414)$ \\
\hline$R^{2}$ & 0.006 & 0.008 & 0.007 & 0.0205 & 0.0184 & 0.029 \\
\hline
\end{tabular}


mation are understated. To obtain robust variance estimates the Huber/White/sandwich estimator of variance for clusters were used in place of the traditional calculation. ${ }^{22}$ All regressions are significant at the $1 \%$ level. The estimation was conducted on the whole sample and on subsamples as well.

As shown in Tables 10 through 12, the estimated coefficients of the acquiring firms' return are positive and significant at every significance level. Moreover they are larger and more significant if the acquiring firm had a negative abnormal return at the announcement just as the preemption theory predicts. In the whole sample the coefficient is smaller than in the subsamples. This is due to the fact that the intercepts weren't restricted to be equal in the two subsample. Rival firms that become targets later have a significantly higher return than those that did not. The effect of the relative total asset size of the rival to the target ( $r_{-}$tta) and the relative Tobin's q of the rival to the target ( $r_{-}$tq) both have negative signs as predicted by the "acquisition probability" hypothesis. All-cash offers, on average, increase the abnormal returns of the rivals although not significantly. Time and the number of rivals are generally not significant. These findings generally support the preemption theory and reject the hubris and agency theories.

\section{Conclusion}

This paper gives a neoclassical economic explanation for the apparent unprofitably of mergers for the acquiring firms. Preemptive motives give a strong reason for why valuedecreasing mergers occur. If a firm fears one of its rivals will gain large cost savings or efficiencies from taking over some third firm, the first firm will rationally preempt this merger with a takeover attempt of its own. By preempting the other firm's bid, the first firm avoids the reduced profits it would have suffered had its rival been successful and thus been able to reduce its own cost of production. But because this argument holds for the rivals to the winners, the acquiring firm sometimes has to pay more than amount of profit gained from the merger.

Empirical tests of this prediction are presented in the second part of this paper. Five hypotheses follow from the preemption theory. The profit-maximizing and the rationality hypotheses cannot be rejected on average but in several cases they seem to be false.

\footnotetext{
${ }^{22}$ The results of fixed effect estimation were similar.
} 
These cases that cannot be explained by the simple value-maximizing theories fit into the preemption theory. Rivals on average had negative abnormal returns when the acquirer had as well, on average at the announcement of the merger. With a slight modification to the benchmark model, called "acquisition probability hypothesis", preemption theory can also account for those rivals whose stock price increased when the acquiring firm lost. The predictions of the preemption theory fits the data much better than either the simple efficiency or hubris and agency models.

\section{References}

[1] Arrow, K. (1962) "Economic Welfare and the Allocation of Resources for Invention" in the Rate and Direction of Inventive Activity: Economic and Social Factors. NBER Conference no. 13. Princeton University Press.

[2] Bradley, M., A. Desai, and H.E. Kim. (1988) "Synergistic Gains from Corporate Control." Journal of Financial Economics 21, pp. 3-40

[3] Betton, S. and B.E. Eckbo (2000) "Toeholds, Bid-Jumps, and Expected Payoffs in Takeovers," Review of Financial Studies forthcoming.

[4] Cramton, P. (1998) "Auctions and Takeovers," in New Palgrave Dictionary of Law and Economics, Peter Neuman (ed.), London: MacMillan Press, 1. pp. 122-125.

[5] Deneckere, R. and Davidson, C. (1985) "Incentives to Form Coalitions with Bertrand Competition," 16. RAND Journal of Economics 16, pp. 473-486.

[6] Eckbo, B. E. (1983) "Horizontal Mergers, Collusion and Stockholder Wealth," Journal of Financial Economics 11, pp. 241-273

[7] Eckbo, B. E. (1985) "Mergers and the Market Concentration Doctrine: Evidence from the Capital Market," Journal of Business 58, pp. 325-349

[8] Eckbo, B. E. (1992) "Mergers and the Value of Antitrust Deterrence," Journal of Finance 48, pp. 1005-1029. 
[9] Eckbo, B. E., Giammarino, R. M. and Heinkel, R. L. (1990) "Asymmetric Information and the Medium of Exchange in Takeovers," Review of Financial Studies 3, pp. 343365.

[10] Eckbo, B. E. and Wier, P. (1985) "Antimerger Policy under the Hart-Scott-Rodino Act: A Reexamination of the Market Power Hypothesis," Journal of Law and Economics 28, pp. 119-149

[11] Farell, J. and Shapiro, C. (1990) "Horizontal Mergers: An Equilibrium Analysis," American Economic Review 80, pp. 107-126.

[12] Fishman, M. J. (1988) "A Theory of Preemptive Takeover Bidding," RAND Journal of Economics 19, pp. 88-101.

[13] Gilbert, R. and Newbery, D. (1982) "Preemptive Patenting and the Persistence of Monopoly," American Economic Review 72, pp. 514-526.

[14] Gowrisankaran, G. (1999) "A Dynamic Model of Endogenous Horizontal Mergers," RAND Journal of Economics 35, pp. 56-83.

[15] Jarrell, G. A., Brickley, J. A. and Netter, J. M. (1988) "The Market for Corporate Control: The Empirical Evidence Since 1980," Journal of Economics Perspectives 2, pp. 49-68.

[16] Jehiel, P. and Moldovanu, B. (2000) "Auctions with Downstream Interaction among Buyers," working paper.

[17] Jensen, M. (1986) "Agency Cost of Free Cash Flow, Corporate Finance and Takeovers," American Economic Review 76, pp. 323-329.

[18] Jensen, M. (1988) "Takeovers: Their Causes and Consequences," Journal of Economic Perspectives 2, pp. 21-48.

[19] Jensen, M. and Ruback R. S. (1983) "The Market for Corporate Control," Journal of Financial Economics 11, pp. 5-50.

[20] Kamien, M. I. (1992) "Patent Licensing," in Handbook of Game Theory, Aumann, R. and Hart, S. (eds.), North-Holland, Amsterdam 
[21] Kamien, M. I. and Tauman, Y. (1984) "The Private Value of a Patent: A Game Theoretic Analysis," Journal of Economics (supplement) 4, pp. 93-118.

[22] Kamien, M. I. and Tauman, Y. (1986) "Fees versus Royalties and the Private Value of a Patent," Quarterly Journal of Economics 101, 471-492.

[23] Kamien, M. I. and Zang, I. (1990) "The Limits of Monopolization Through Acquisition," Quarterly Journal of Economics 105, 465-499.

[24] Kamien, M. I. and Zang, I. (1991) "Competitively Cost Advantageous Mergers and Monopolization," Games and Economic Behavior 3, pp. 323-338.

[25] Kamien, M. I. and Zang, I. (1993) "Monopolization by Sequential Acquisition," Journal of Law, Economics, and Organization 9, pp. 205-229.

[26] Katz, M. and Shapiro, C. (1985) "On the Licensing of Innovations," Rand Journal of Economics 16, 504-520.

[27] Katz, M. and Shapiro, C. (1986) "How to Licence Intangible Property," Quarterly Journal of Economics 101, 567-590.

[28] Levin, D. (1990) "Horizontal Mergers: The 50-Percent Benchmark," American Economic Review 80, pp. 1238-1245.

[29] Molnar, J. (2000) "Auctions with endogenous externalities and signaling," work in progress.

[30] Myers, S. C. and Majluf, N. S. (1984) "Corporate Financing and Investment Decisions When Firms Have Information Investors Do Not Have," Journal of Financial Economics 13, pp. 197-221.

[31] Perry, M. K. and Porter, R. H. (1985) "Oligopoly and the Incentive for Horizontal Merger," American Economic Review 75, pp. 219-227.

[32] Roll, R. (1986) "The Hubris Hypothesis of Corporate Takeovers," Journal of Business 59, pp. 197-216. 
[33] Queen, M. (1989) "Market Anticipation of Corporate Takeover and the Gain for the Bidders," unpublished doctoral dissertation, The Anderson School at UCLA.

[34] Salant, S. W., Switzer, S. and Reynolds, R. J. 1983. "Losses from Horizontal Merger: The Effects of an Exogenous Change in Industry Structure on Cournot-Nash Equilibrium," Quarterly Journal of Economics 98, pp. 185-199.

[35] Sirower, M. L. (1997) "The Synergy Trap. How Companies Lose the Acquisition Game," The Free Press, New York.

[36] Song, M. H. and Walkling, R. A. (2000) "Abnormal returns to rivals of acquisition targets: A test of the 'acquisition probability' hypothesis," Journal of Financial Economics 55, pp.143-171.

[37] Schwert, W. G. (1996) "Markup Pricing in Mergers and Acquisitions," Journal of Financial Economics 41, pp. 153-192.

[38] Stigler, G. (1950) "Monopoly and Oligopoly by Merger," American Economic Review 40, pp. 23-34.

[39] Stillman, R (1983) "Examining Antitrust Policy Towards Horizontal Mergers," Journal of Financial Economics 11, pp. 224-240.

[40] Trevlos, N. G. (1987) "Corporate Takeover Bids, Method of Payment, and Bidding Firms' Stock Returns," Journal of Finance 42, pp. 943-963.

[41] U.S. Department of Justice and Federal Trade Commission. (1992) "Horizontal Merger Guidelines"

[42] Weston, J. F., Chung, S. K. and Siu, J.A. (1997) "Takeovers, Restructuring and Corporate Governance," 2nd edition Prentice-Hall, Inc.

[43] Williamson, E. O. (1968) "Economies as an Anti-Trust Defence: The Welfare TradeOff," American Economic Review 58, pp. 18-36. 